\title{
The Influence of Selected Osmotic Dehydration and Pretreatment Parameters on Dry Matter and Polyphenol Content in Highbush Blueberry (Vaccinium corymbosum L.) Fruits
}

\author{
Anna Kucner • Robert Klewicki • Michał Sójka \\ Received: 2 January 2012 / Accepted: 31 October 2012 / Published online: 24 November 2012 \\ (C) The Author(s) 2012. This article is published with open access at Springerlink.com
}

\begin{abstract}
The paper presents an assessment of the influence of selected highbush blueberry pretreatment methods and parameters on the process of osmotic dehydration conducted in $65^{\circ}$ Brix sucrose solution for 5 to $240 \mathrm{~min}$ at $30-70{ }^{\circ} \mathrm{C}$. The pretreatment methods used included: fruit immersion in boiling water $(15 \mathrm{~s})$ and in $0.5 \% \mathrm{NaOH}$ solution $(15 \mathrm{~s}$ at $95{ }^{\circ} \mathrm{C}$ ), exposure to ultrasound at atmospheric pressure (vibration frequency of $35 \pm 5 \mathrm{kHz}, 500 \mathrm{~W}$, for $15 \mathrm{~min}$.) and at low pressure $\left(0.92 \mathrm{~kg} \mathrm{~cm}^{-1}\right)$, and enzymatic processing; pectinase (enzyme activity of $46,000 \mathrm{PGU} / \mathrm{mL} ; 0.6 \mathrm{~mL} /$ $90 \mathrm{~g}$ of fruits; $30 \mathrm{~min}$ at approx. $22{ }^{\circ} \mathrm{C}$ ) and lipase (enzyme activity of $750 \mathrm{PGU} / \mathrm{mL} ; 0.7 \mathrm{~mL} / 90 \mathrm{~g}$ of fruits; $30 \mathrm{~min}$ at approx. $22{ }^{\circ} \mathrm{C}$ ) were used. Dehydration was also conducted in the presence of pectinolytic enzymes. The dehydrated material was analyzed in terms of the content of dry matter, total polyphenols, and particular polyphenols using high performance liquid chromatography. It was observed that dehydration was much more intensive at 60 and $70{ }^{\circ} \mathrm{C}$, but such temperatures led to substantial losses of phenolic compounds (by $15-30 \%$ after 2-h dehydration) and unfavorable changes in the texture of the final product. A promising method of pretreatment is fruit immersion in solutions containing pectinolytic and lipolytic enzymes, which increase dry matter content by $26 \%$ (after $1 \mathrm{~h}$ of dehydration at $30{ }^{\circ} \mathrm{C}$ ) with a low loss of phenolic compounds $(4 \%)$. Among the identified anthocyanins, the greatest retention during dehydration at various temperatures was displayed by petunidin-3-galactoside (over $80 \%$ after $1 \mathrm{~h}$ of dehydration) and petunidin-3-glucoside (over $78 \%$ ).
\end{abstract}

A. Kucner $\cdot$ R. Klewicki $(\bowtie) \cdot$ M. Sójka Institute of Chemical Technology of Food, Lodz University of Technology, 4/10 Stefanowskiego Street, 90-924 Łódź, Poland

e-mail: robert.klewicki@p.lodz.p1
Keywords Osmotic dehydration $\cdot$ Pretreatment $\cdot$ Highbush blueberry $\cdot$ Polyphenols

\section{Introduction}

Highbush blueberry (Vaccinium corymbosum L.) fruits have a unique aromatic taste and a wealth of valuable nutrients (Mazza 2005; Skupień 2006; Ochmian et al. 2009). The nutritional qualities of the berries are attributed to the presence of phenolic compounds (Joseph et al. 2005; Yi et al. 2006; Zafra-Stone et al. 2007; Krikorian et al. 2010). Albeit not essential for human life, flavonoids may act as a healthimproving factor, if consumed over a long period of time. These compounds exhibit antioxidant activity, thus being supportive to the natural defenses of the human body and decreasing the risk of developing diseases of civilization (Pietta 2000; Heim et al. 2002; Petti and Scully 2009). Clinical studies confirm that the biological activity of natural antioxidants is higher than that of corresponding pharmacological supplements (Wang et al. 1996; Manach et al. 2004; Pokorný 2007; Perron and Brumaghim 2009). Highbush blueberries are a rich source of anthocyanins and contain monoglycosides (glucosides, galactosides, and arabinosides) of delphinidin, cyanidin, petunidin, peonidin, and malvidin, as well as their acyl derivatives (Gao and Mazza 1994; Kalt et al. 1999; Wu and Prior 2005; Krupa and Tomala 2007; Barnes et al. 2009). The most abundant phenolic acid is chlorogenic acid (Cho et al. 2004; Taruscio et al. 2004; Wang et al. 2008); other acids include hydroxybenzoic acids (gentisic, gallic, protocatechuic, and salicylic acids) and hydroxycinnamic acids (m-coumaric, ocoumaric, and p-coumaric) occurring in the form of esters or glycosides (Zadernowski et al. 2005). Polyphenols characteristic of the highbush blueberry include flavonols, represented mostly by quercetin and its derivatives (Cho et al. 
2005, 2004; Zheng and Wang 2003). The presence of proanthocyanidins has also been detected (Gu et al. 2003; 2004).

Due to the seasonality of highbush blueberry fruits, fresh berries are available only for a few months a year. One of the methods of extending the postharvest life of blueberries is osmotic dehydration, which also makes it possible to modify the composition of the raw material. The process consists in immersing raw material of cellular structure in a hypertonic solution (Behsnilian and Spiess 2006). During the process, the water present in the tissues is removed to the solution and mass is transferred between the solution and tissue components. Results obtained by Saurel et al. (1994a) indicate that the gradient of osmotic pressure created between the osmotic solution and the vacuolar sap of the fresh material subjected to dehydration is the major driving force of the process at low temperatures and short processing times (under $50{ }^{\circ} \mathrm{C}$ and up to $30 \mathrm{~min}$ for apples). Water and substances from the sap are transported through the semipermeable cell membrane of the biological material. The state of the membrane may change from partial to full permeability, which depends on the process conditions (Torreggiani and Bertolo 2001). According to Saurel et al. (1994a), at higher temperatures and long process times transfers are controlled by diffusion phenomena. Thus, inadequate dehydration parameters may lead to unfavorable changes in the dehydrated material, including the loss of semipermeability of cell membranes and substantial losses of valuable nutrients (Chiralt and Talens 2005; Falade and Igbeka 2007) as well as high sugar impregnation, which increases the caloric value of the product. During dehydration of frozen fruits, where penetration of the fruit tissue by osmotic substance is more intensive as the structure of cellular material is more damaged (Ohnihisi et al. 2003), the dehydration principle is also based on an overall diffusion mechanism (Saurel et al. 1994b).

A factor that hampers mass transfer in the process of osmotic dehydration is the fruit epidermis. Due to its low permeability, it constitutes a barrier to the osmotic solution, water, and substances dissolved in vacuolar sap. Consequently, in many cases, it is necessary to pretreat the raw material. The various pretreatment methods proposed in the literature include: ultrasound, lower hydrostatic pressure, steaming, immersion in alkaline or salt solutions, and exposure to a highintensity electric field. Rodrigues et al. (2009) used ultrasound in the experiments on sapota fruits. Samples were peeled, cut into slices, immersed in water, and subjected to ultrasonic waves for 10-30 min. Fernandes et al. (2009) evaluated the effect of ultrasound on pineapple tissue (near triangular shaped samples were pretreated under the above-mentioned conditions). Ultrasound was also tested on banana, genipap, jambo, melon, papaya, and pinha (Fernandes and Rodrigues 2008). In the experiments by Mújica-Paz et al. (2003), vacuum was used at the first stage of osmotic dehydration (10 $\mathrm{min})$ of mango, apple, and melon. Vacuum was also used by Bórquez et al. (2010). Defrozen raspberries were osmo-dehydrated initially at low pressure (for $8 \mathrm{~min}$ ) and then at ambient pressure (4 h). Grabowski et al. (2007) performed a chemical pretreatment. Cranberries were dipped into $0.5-2.0 \% \mathrm{NaOH}$ solution for 3 min at $20^{\circ} \mathrm{C} ; 3 \%$ sodium oleate and ethyl oleate were also tested. Additionally, different thermal pretreatments ( $3 \mathrm{~min}$ at $\left.100{ }^{\circ} \mathrm{C}\right)$ were evaluated. High-intensity electric field $(0.2$ $1.6 \mathrm{kV} / \mathrm{cm}$ ) was applied by Rastogi et al. (1999) before osmotic dehydration of carrots. Most of the abovementioned pretreatments led to the increase in the mass transfer during osmotic dehydration, albeit in different degrees.

The objective of this work was to examine the influence of the temperature and duration of the dehydration process as well as the methods of pretreatment on polyphenol content in highbush blueberry fruits.

\section{Materials and Methods}

\section{Materials}

This study examined frozen highbush blueberry fruits of the cultivar "Bluecrop" (in the consumer maturity phase; $\mathrm{pH}=3.47$; dry matter content was $19.3 \mathrm{~g} / 100 \mathrm{~g}$; average mass of fresh fruit $1.9 \mathrm{~g} \pm 0.3 \mathrm{~g}$ ) harvested in late July and early August 2010 from a plantation located in Konstantynów Łódzki, Poland. The fruits were stored at $-18{ }^{\circ} \mathrm{C}$.

\section{Chemicals and Standards}

Methanol, acetone, and formic acid were purchased from J.T. Baker (Witko, Poland) Ultrapure water (Millipore System) was used to prepare all solutions. Commercial standards of delphinidin-3-O-glucoside, cyanidin-3-O-galactoside, cyanidin-3-O-glucoside were purchased from Extrasynthèse (Genay, France). Folin-Ciocalteu's phenol reagent was obtained from POCH s.a. (Gliwice, Poland) and (-)-epikatechin standard was purchased from Sigma Aldrich (Steinheim, Germany). The enzymes PectinexYeld Mash, Palatase 750-L were provided by Novozymes (Bagsvaerd, Denmark), and Rapidase C-80 Max was supplied by DSM Food Specialties-Beverage Ingredients (Delft, Netherlands).

\section{Osmotic Dehydration Without Pretreatment}

The frozen fruits were dehydrated in $65^{\circ}$ Brix sucrose solution. Samples of $13.5 \pm 1.0 \mathrm{~g}$ (approx. six berries) were weighed into plastic containers with screw-on lids. The solution was added to the containers immediately before the experiment, and then the sucrose solution was heated up to the dehydration temperature. The weight ratio of the raw material to the solution was 1:4. The process of osmotic dehydration (OD) was conducted 
for $5,15,30,60,90,120,180$, and $240 \mathrm{~min}$ at $30,40,50,60$, and $70{ }^{\circ} \mathrm{C}$ under atmospheric pressure (the average time required to reach the desired temperature was $60 \mathrm{~min}$ following the dipping of frozen fruits). Every experiment was done in duplicate. Continuous shaking was applied throughout osmotic dehydration (200 cycles/min). After the set time of dehydration, the fruits were separated from the osmotic solution by means of a sieve. They were subsequently immersed in water and dried with filter paper. The dehydrated material was analyzed in terms of the content of dry matter, total polyphenols, and individual polyphenols using high performance liquid chromatography (HPLC).

Pretreatment of Fruits Prior to Osmotic Dehydration

\section{Immersion in Boiling Water}

Samples of $13.5 \pm 1.0 \mathrm{~g}$ of the fruits (kept at approx. $22{ }^{\circ} \mathrm{C}$ for $15 \mathrm{~min}$ after taking out from a freezer) were placed on sieves and immersed in boiling water for $15 \mathrm{~s}$. Subsequently, the fruits were cooled down by immersion in cold water.

\section{Immersion in Hot $\mathrm{NaOH}$ solution}

Samples of $13.5 \pm 1.0 \mathrm{~g}$ of the fruits (kept at approx. $22{ }^{\circ} \mathrm{C}$ for $15 \mathrm{~min}$ after taking out from a freezer) were placed on sieves and immersed in $0.5 \%$ solution of $\mathrm{NaOH}$ for $15 \mathrm{~s}$ at $95{ }^{\circ} \mathrm{C}$. Subsequently, the fruits were cooled down by immersion in cold water.

\section{Ultrasound Treatment}

Plastic containers with $13.5 \pm 1.0 \mathrm{~g}$ of sample material: fruits (kept at approx. $22{ }^{\circ} \mathrm{C}$ for 15 min after taking out from a freezer) and solution at a ratio of 1:4 were placed in an ultrasonic cleaner (Inter Sonic; $2,000 \mathrm{~mL}$, vibration frequency of $35 \pm 5 \mathrm{kHz}, 500 \mathrm{~W}$ ) for $15 \mathrm{~min}$.

\section{Ultrasound and Low Pressure Treatment}

Samples of $13.5 \pm 1.0 \mathrm{~g}$ of the fruits (kept at approx. $22{ }^{\circ} \mathrm{C}$ for 15 min after taking out from a freezer) and osmotic solution (at a ratio of 1:4) were placed in $150 \mathrm{~mL}$ vacuum flasks. Subsequently, the flasks were sealed tight and connected to a vacuum pump $\left(0.92 \mathrm{~kg} \mathrm{~cm}^{-1}\right)$. After $15 \mathrm{~min}$, the flasks were disconnected from the vacuum pump and exposed to ultrasound (Inter Sonic; $2,000 \mathrm{~mL}$, vibration frequency of $35 \pm 5 \mathrm{kHz}, 500 \mathrm{~W}$ ) for $15 \mathrm{~min}$.

\section{Treatment with Pectinolytic and Lipolytic Enzymes}

First, $90 \pm 1 \mathrm{~g}$ of the fruits (kept at approx. $22^{\circ} \mathrm{C}$ for $15 \mathrm{~min}$ after taking out from a freezer) was weighed into a $600 \mathrm{~mL}$ beaker, after which $360 \mathrm{~mL}$ of water and $0.6 \mathrm{~mL}$ of Pectinex Yield Mash preparation (enzyme activity of $46,000 \mathrm{PGU} / \mathrm{mL}$ ) were added, and the beaker was left to stand for $30 \mathrm{~min}$ at approx. $22^{\circ} \mathrm{C}(\mathrm{pH}$ amounted to $4.2 \pm 0.2$ ). The fruits were then separated from the solution and washed with water three times. Subsequently, $13.5 \pm 1 \mathrm{~g}$ fruit samples were weighed into containers with screw-on lids and $65 \%$ sucrose solution was added.

The same procedure was used for the lipolytic preparation Palatase $750-\mathrm{L}(0.7 \mathrm{~mL}$, enzyme activity of $750 \mathrm{PGU} /$ $\mathrm{mL}$ ). Prior to the addition of lipase, the water (with fruits) was brought to $\mathrm{pH} 6.5 \pm 0.5$ with $0.1 \mathrm{M} \mathrm{NaOH}$.

Furthermore, in another variant, the fruits were first subjected to treatment with lipolytic enzymes and then pectinolytic enzymes, in accordance with the above procedures.

Osmotic Dehydration Following Pretreatment

Osmotic dehydration was carried out at $30{ }^{\circ} \mathrm{C}$. The other conditions of the process as well as the steps taken after its completion were as specified in point Osmotic Dehydration Without Pretreatment.

Osmotic Dehydration in the Presence of Pectinolytic Enzymes

Samples of $13.5 \pm 1.0$ of raw material (kept at approx. $22{ }^{\circ} \mathrm{C}$ for $15 \mathrm{~min}$ after taking out from a freezer) were placed on a sieve and immersed in boiling water for $15 \mathrm{~s}$. Subsequently, they were placed in plastic containers with screw-on lids, to which $65^{\circ}$ Brix sucrose solution was added (at a fruit to syrup ratio of 1:4 $w / w)$. The sucrose solution had been brought to $\mathrm{pH} 3.5 \pm 0.5$ prior to addition. A pectinolytic enzyme was added to every container. The following enzymatic preparations were used: Pectinex Yield Mash (Novozymes) and Rapidase C-80 Max (DSM); $0.1 \mathrm{~mL}$ of the preparations was added per $60 \mathrm{~g}$ of the osmotic solution. The remaining dehydration conditions were as in Osmotic Dehydration Without Pretreatment.

\section{Phenolic Extraction}

After dehydration, each sample (including all fruits from a container) was ground under liquid nitrogen with a grinder (A11B, IKA, Germany). Subsequently, $2.0 \pm 0.5 \mathrm{~g}$ of a sample was weighed and extracted five times over $15 \mathrm{~min}$ with a solution containing $\mathrm{MeOH}, \mathrm{H}_{2} \mathrm{O}$ and $\mathrm{HCOOH}(50: 48: 2)$ by decanting the supernatant to $25 \mathrm{~mL}$ volumetric flasks. The flasks were filled to volume with the extraction solution.

Determination of Total Polyphenol Content

First, $0.5 \mathrm{~mL}$ of the extract obtained as specified in Phenolic Extraction, $0.25 \mathrm{~mL}$ of Folin-Ciocalteu reagent, and $2.5 \mathrm{~mL}$ of $20 \% \mathrm{Na}_{2} \mathrm{CO}_{3}$ were placed in $25 \mathrm{~mL}$ volumetric flasks. Then, the flasks were filled to the mark with distilled water, and the 
contents were mixed and incubated at room temperature for $1 \mathrm{~h}$. The absorbance of the solutions was measured at a wavelength of $720 \mathrm{~nm}$. Total polyphenol content was expressed as (-)epicatechin equivalents (Singleton and Rossi1965).

Determination of Anthocyanin Content with the HPLC Method

Chromatographic analysis was performed using a Knauer HPLC chromatograph with Phenomenex Gemini 5u C18 110 A columns $[150 \times 4.60 \mathrm{~mm}]$ with a Phenomenex Security Guard Cartridge system $[4 \times 3.0 \mathrm{~mm}]$ and a DAD detector at $40{ }^{\circ} \mathrm{C}$ and a flow rate of $1 \mathrm{mlmin}^{-1}$; phase $\mathrm{A}: \mathrm{H}_{2} \mathrm{O} / \mathrm{HCOOH}$ $(9: 1, v / v)$ and phase B: ACN/ $\mathrm{H}_{2} \mathrm{O} / \mathrm{HCOOH}(95: 4: 1, v / v)$. The gradient program was as follows: $0-0.6 \mathrm{~min}, 12 \%(v / v) \mathrm{B} ; 0.6-$ $16 \mathrm{~min}, 12-30 \%(v / v) \mathrm{B} ; 16-20.5 \min 30-100 \%(v / v) \mathrm{B} ; 20.5-$ $22 \min , 100 \%(v / v) \mathrm{B} ; 22-25 \min , 100-12 \%(v / v) \mathrm{B}, 25-$ $35 \mathrm{~min}, 12 \%(v / v)$ B. The injection volume was $20 \mu \mathrm{L}$. Data were collected using the Eurochrom 2000 software (Knauer, Berlin, Germany). Separation was performed on extract obtained as specified in Phenolic Extraction.

The total phenolics were measured by the method described by Singleton and Rossi 1965 with some modification. Standards obtained from Extrasynthèse (Geny, France) and SigmaAldrich, UV-vis data, and LC-MS data, as well as literature data (Gao and Mazza 1994; Kalt et al. 1999; Häkkinen and Törrönen 2000; Wu and Prior 2005; Castrejón et al. 2008; Lohachoompol et al. 2008; You et al. 2011), were used for the identification of anthocyanins. Quantitative results of the determinations are given as cyanidin-3-glucoside equivalents.

\section{LC-ESI-MS/MS Analysis}

The frozen fruits were extracted as specified in Phenolic Extraction. Then, the samples were separated using a Knauer System (Determination of Anthocyanin Content with the HPLC
Method) equipped with fraction collector FOXY R1 (Teledyne ISCO Lincoln, NE, USA). Peaks were collected from ten repeated HPLC separations of extract. The obtained samples were diluted (1:3) with distilled water. The samples were passed through the SPE columns (STRATA X, Phenomenex, UK) that were pre-conditioned with $1 \mathrm{~mL} 100 \% \mathrm{MeOH}$ and $1 \mathrm{~mL} \mathrm{H}_{2} \mathrm{O}$. The retained compounds were eluted using $1 \mathrm{~mL}$ of $100 \%$ $\mathrm{MeOH}$. These solutions were then subjected to LC-ESI-MS/MS (LTQ VETOS, Thermo Scientific, Waltham, MA, USA). The samples were directly injected into MS detector. Analyses utilized the positive ion mode. The source parameters were as follows: ion spray voltage, $3.00 \mathrm{kV}$; capillary temperature, $325^{\circ} \mathrm{C}$; and sheath gas and auxiliary gas, 30 and 10 units $/ \mathrm{min}$, respectively. To generate MS/MS data, the precursor ions were by helium gas collision in the ion trap by optimizing the collision energy in order to obtain an intensity of the precursor ion close to $10 \%$ of the relative scale of the spectrum.

\section{Determination of Dry Matter Content}

A weighing bottle with a glass rod and $5 \pm 1 \mathrm{~g}$ of sand was placed in a dryer at $105 \pm 2{ }^{\circ} \mathrm{C}$ for $1 \mathrm{~h}$ until a constant weight was obtained. Subsequently, the bottle was cooled down in a desiccator and weighed. Then, $2 \pm 0.5 \mathrm{~g}$ of sample material (after grinding, see "Phenolic Extraction") was weighed into the bottle, mixed with the sand, and weighed. After weighing, the bottle containing the sample material was dried to constant weight in a vacuum dryer $(90.0 \mathrm{kPa})$ at $60 \pm 2{ }^{\circ} \mathrm{C}$ for $10 \mathrm{~h}$. Finally, the bottle was cooled down in a desiccator and weighed.

\section{Calculation of Osmotic Parameters}

In order to calculate water loss (WL) and solids gain (SG), the following formulas were used (Matuska et al. 2006):

$$
\begin{array}{ll}
\mathrm{WL}=\left[\mathrm{m}_{0}\left(1-\mathrm{s}_{0}\right)-\mathrm{m}_{\mathrm{k}}\left(1-\mathrm{s}_{\mathrm{k}}\right)\right] / \mathrm{m}_{0} \mathrm{~s}_{0} & {\left[\mathrm{~g} \mathrm{H}_{2} \mathrm{O} / \mathrm{g} \text { initial dry matter }\right]} \\
\mathrm{SG}=\left(\mathrm{m}_{\mathrm{k}} \mathrm{s}_{\mathrm{k}}-\mathrm{m}_{0} \mathrm{~s}_{0}\right) / \mathrm{m}_{0} \mathrm{~s}_{0} & {[\mathrm{~g} \text { dry matter } / \mathrm{g} \text { initial dry matter }]}
\end{array}
$$

$m_{0} \quad$ weight of sample before osmotic dehydration [grams]

$m_{\mathrm{k}} \quad$ weight of sample after osmotic dehydration [grams]

$s_{0} \quad$ solids content before osmotic dehydration [grams of dry matter per gram]

$s_{\mathrm{k}} \quad$ solids content after osmotic dehydration [grams of dry matter per gram]

Statistical Analysis

ANOVA analysis was conducted using STATISTICA software to evaluate differences between treatments (by Duncan's test).

\section{Results and Discussion}

Changes of Dry Matter Content During Fruit Dehydration Without Pretreatment

Changes of dry matter content, water loss, and solids gain in highbush blueberries subjected to dehydration are presented in Fig. 1. The sucrose solution to fruit ratio was 4 to 1 , which, according to literature data, ensures appropriate dehydration conditions by protecting the osmotic solution against excessive dilution with water (Rastogi et al. 2002). The presented results show that dehydration at 30 to $50{ }^{\circ} \mathrm{C}$ did not proceed very 
Fig. 1 Changes in dry matter content (a), water loss (b), and solids gain (c) in highbush blueberry fruits during osmotic dehydration (OD) in $65^{\circ}$ Brix sucrose solution at 1:4 fruit to syrup ratio at different temperatures $\left(30,40,50,60\right.$, and $\left.70^{\circ} \mathrm{C}\right)$. In the tables attached, the same letter in different cells within a given column indicates a lack of statistical differences $(\alpha=0.05)$ between the results at particular processing times
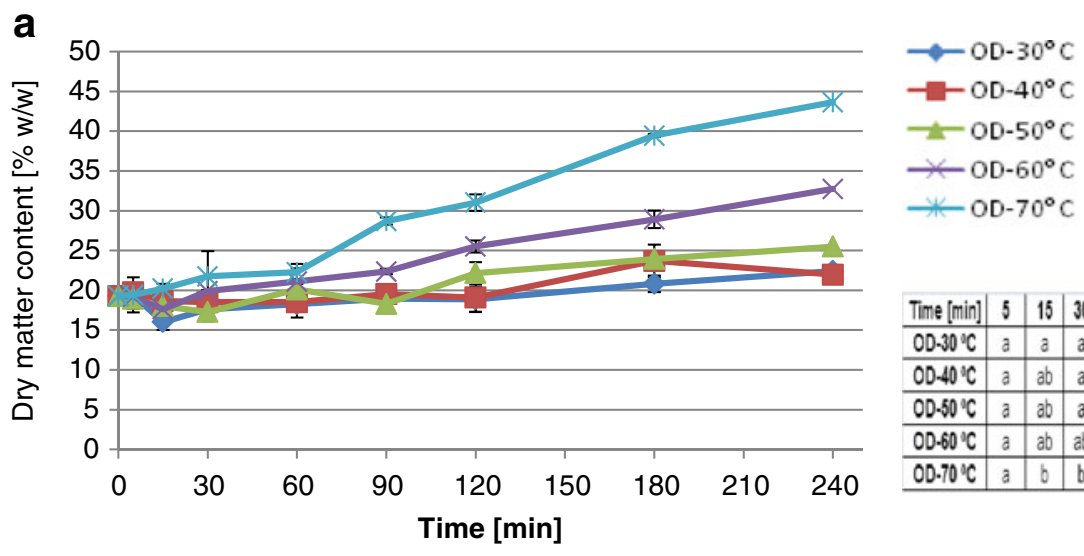

b
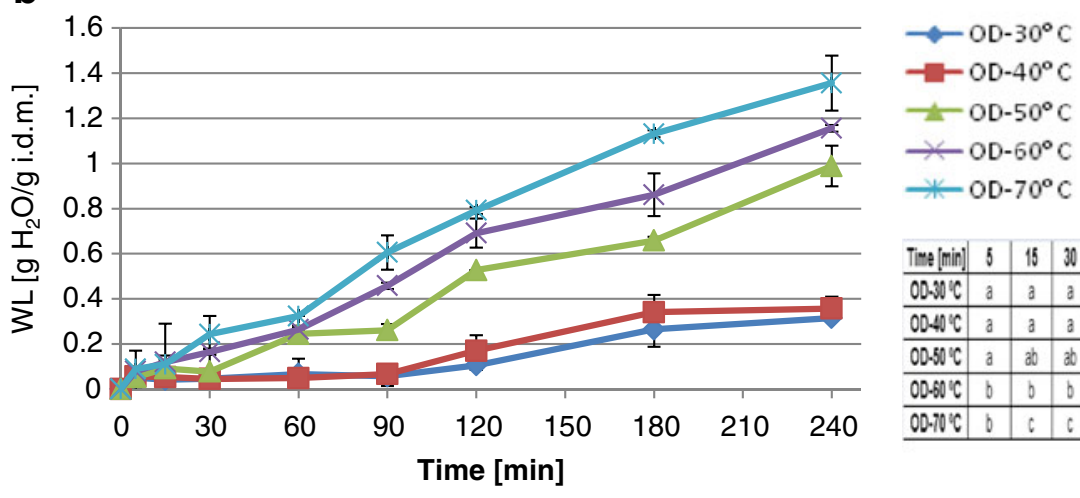

\begin{tabular}{l|l|l|l|l|l|l|l|l|} 
Time [min] & 5 & 15 & 30 & 60 & 90 & 120 & 180 & 240 \\
\hline
\end{tabular}

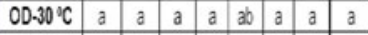
\begin{tabular}{l|l|l|l|l|l|l|l|l}
\hline$O D-40^{\prime} \mathrm{C}$ & $a$ & $a b$ & $a$ & $a$ & $a b$ & $a$ & $a$ & $a$ \\
\hline$O D-N O C$ & $a$ & $b$ & $a$ & $a$ & $a$ & $b$ & $a$ & $b$
\end{tabular}

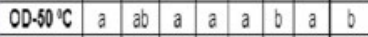

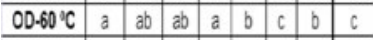
\begin{tabular}{|l|l|l|l|l|l|l|l|l|}
\hline $00.70^{\circ} \mathrm{C}$ & $a$ & $b$ & $b$ & $a$ & $c$ & $d$ & $c$ & $d$ \\
\hline
\end{tabular}

C

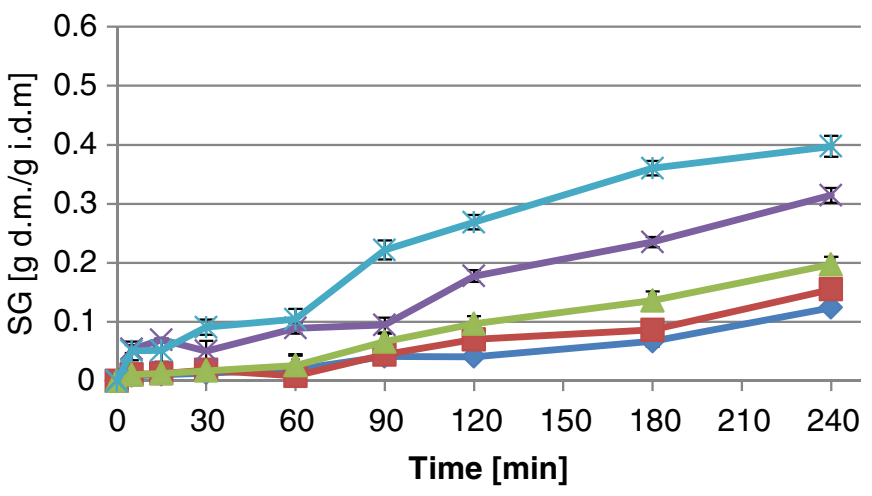

effectively. After $180 \mathrm{~min}$, the increase in dry matter was $7.8,22.7$, and $24.0 \%$ at 30,40 , and $50{ }^{\circ} \mathrm{C}$, respectively. Water loss amounted to 0.27 and $0.34 \mathrm{~g} \mathrm{H}_{2} \mathrm{O} / \mathrm{g}$ i.d.m. at 30 and $40{ }^{\circ} \mathrm{C}$, respectively (Fig. 1b). At $50{ }^{\circ} \mathrm{C}$, higher WL (0.66 $\mathrm{g} \mathrm{H}_{2} \mathrm{O} / \mathrm{g}$ i.d.m.) was observed; however, it did not yet translate into a significantly higher dry matter content. Solids gain was at a low level, amounting to $0.07-0.14 \mathrm{~g}$ d.m./g i.d.m. (Fig. 1c). At 60 and $70{ }^{\circ} \mathrm{C}$, dehydration proceeded faster, but it also took a relatively long time to obtain a highly dehydrated product. At $60{ }^{\circ} \mathrm{C}$, dry matter content increased by $32 \%$ after $120 \mathrm{~min}$, while at $70{ }^{\circ} \mathrm{C}$ by about $61 \%$. Water loss amounted to $0.69 \mathrm{~g}$ $\mathrm{H}_{2} \mathrm{O} / \mathrm{g}$ i.d.m. and $0.79 \mathrm{~g} \mathrm{H}_{2} \mathrm{O} / \mathrm{g}$ i.d.m., respectively. After
$3 \mathrm{~h}$ of processing, dry matter content significantly increased (by $49.7 \%$ at $60{ }^{\circ} \mathrm{C}$ and twofold at $70{ }^{\circ} \mathrm{C}$ ). At $60^{\circ} \mathrm{C}$, WL and SG reached a level of $0.86 \mathrm{~g} \mathrm{H}_{2} \mathrm{O} / \mathrm{g}$ i.d.m. and $0.24 \mathrm{~g}$ d.m./g i.d.m., respectively, while at $70{ }^{\circ} \mathrm{C}$ a level $1.13 \mathrm{~g} \mathrm{H}_{2} \mathrm{O} / \mathrm{g}$ i.d.m. and $0.36 \mathrm{~g}$ d.m./g i.d.m., respectively. Much lower values for blueberry dehydration were observed by Nsonzi and Ramaswamy (1998). In their experiments, an increase in dry matter content after $180 \mathrm{~min}$ at 40,50 , and $60{ }^{\circ} \mathrm{C}$ was 3,6 , and $9.5 \%$, respectively. The use of high temperatures for accelerating the dehydration process entailed unfavorable changes in the processed material. As early as after $60 \mathrm{~min}$, the fruits started to soften and acquired unfavorable texture. Furthermore, thermal processing may lead to the loss of semipermeability of cell 
membranes and accelerate the chemical reactions occurring inside the dehydrated material (Lewicki et al. 1998).

The presented results show that osmotic dehydration at $30-50{ }^{\circ} \mathrm{C}$ is time consuming and does not deliver an adequate degree of dehydration. Therefore, further research focused on finding a pretreatment method that would ensure better mass transfer.

\section{Changes in Dry Matter Content in Pretreated Fruits}

Figure 2a shows the influence of treating the material with hot $0.5 \%$ solution of $\mathrm{NaOH}$ on changes in dry matter content during osmotic dehydration. In comparison to the control, which is material dehydrated without pretreatment, no sizeable changes in dry matter content were observed, although both some transfer of water from the tissue (Fig. 2b) and migration of osmotic agent to the tissue (Fig. 2c) were observed. The above pretreatment methods were designed to disturb the external waxy layer protecting the fruits against water loss (Skurtys et al. 2011), but they did not bring the expected results, namely, a more intensive mass transfer. The literature provides an example of pretreating cranberries with $0.5 \mathrm{M} \mathrm{NaOH}$ solution in the process of osmo-convective drying (Grabowski et al. 2007).

Interesting pretreatment methods include the use of ultrasound and low pressure. The action of acoustic waves (ultrasounds) on plant tissue leads to a series of contractions and removal of water, resulting in an effect similar to squeezing a sponge. This treatment method induces the formation of microscopic channels and improves the capillary flow of osmotic solution to intercellular spaces in the material subjected to dehydration (Fernandes et al. 2009). Furthermore, it has been shown that the process of osmotic dehydration with sonification facilitates water diffusion during convective drying. Similar effects were reported by Fernandes and Rodrigues (2011) in the process of drying pineapples, Malay apples, and soapberries.
Fig. 2 Changes in dry matter content (a), water loss (b), and solids gain (c) in highbush blueberry fruits during osmotic dehydration at $30^{\circ} \mathrm{C}$ : without pretreatment $\left(\mathrm{OD}-30{ }^{\circ} \mathrm{C}\right)$; preceded by pretreatment in hot water $\left(\mathrm{HW}+\mathrm{OD}-30{ }^{\circ} \mathrm{C}\right)$; preceded by pretreatment in hot water and in hot $\mathrm{NaOH}$ at $100{ }^{\circ} \mathrm{C}(\mathrm{HW}+\mathrm{NaOH}+\mathrm{OD}-$ $\left.30{ }^{\circ} \mathrm{C}\right)$. In the tables attached, the same letter in different cells within a given column indicates a lack of statistical differences ( $\alpha=0.05)$ between the results at particular processing times a

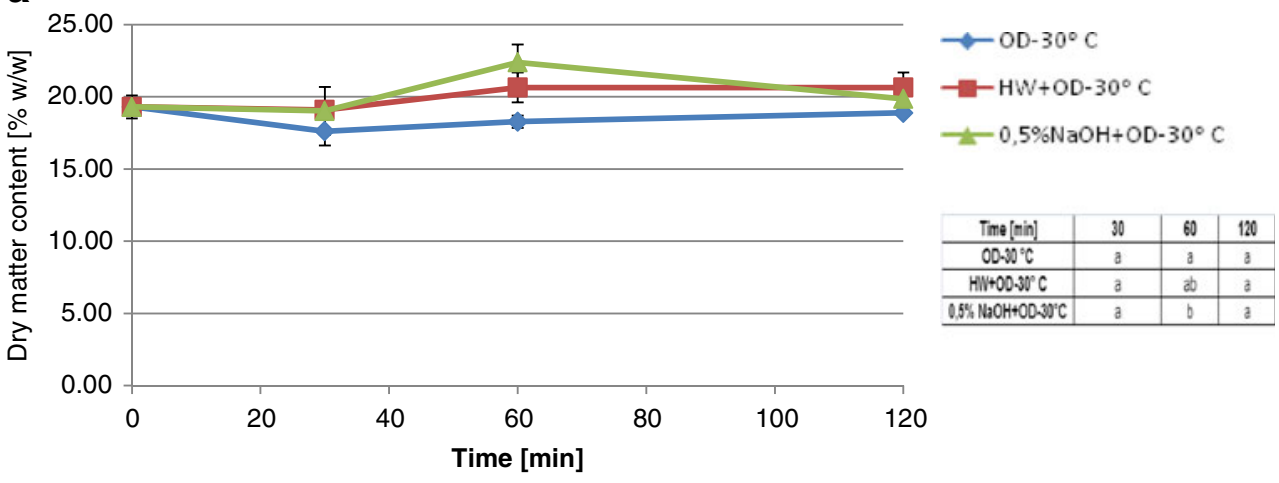

b
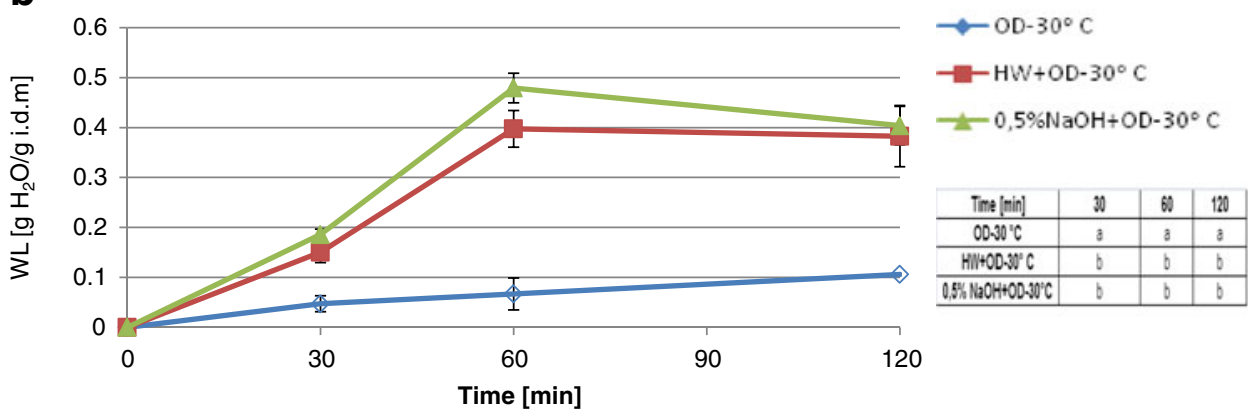

C

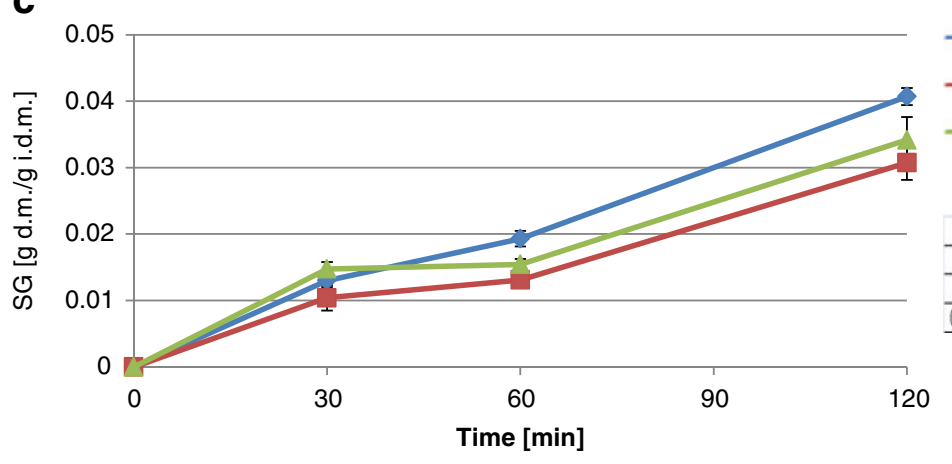

$\because \mathrm{OD}-30^{\circ} \mathrm{C}$

$\rightarrow-\mathrm{HW}+\mathrm{OD}-30^{\circ} \mathrm{C}$

$-0,5 \% \mathrm{NaOH}+\mathrm{OD}-30^{\circ} \mathrm{C}$

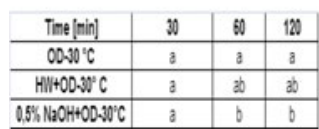


Literature data also confirm that dehydration under low pressure proceeds faster as compared to samples dehydrated under atmospheric pressure. Low pressure pretreatment makes it possible to remove the gas present in the pores of the raw material, which leads to an increased surface of mass transfer and facilitates further dehydration under atmospheric pressure (Rastogi et al. 2002). This method decreases the time of dehydration, thus reducing energy consumption in further technological processes (Deng and Zhao 2008; Janowicz et al. 2008).

In our experiments, the action of ultrasound had no significant effect on dry matter content of blueberries. Ultrasound combined with low pressure only moderately improved osmotic dehydration (Fig. 3a). After 60 and 120 min dry matter content increased by 10 and $13 \%$, respectively. In both cases, some water migration was observed; the WL level was about $0.6 \mathrm{~g} \mathrm{H}_{2} \mathrm{O} / \mathrm{g}$ i.d.m. after $2 \mathrm{~h}$ (Fig. 3b). Solids gain was very low and amounted to approx. $0.04 \mathrm{~g}$ d.m./g i.d.m. In the case of using vacuum, WL and SG were more intensive in the first phase of the process as compared to dehydration performed under atmospheric pressure.

From the point of view of increasing dry matter content, a good method of dehydration is using solutions containing pectinolytic enzymes (Fig. 4). After $1 \mathrm{~h}$ of dehydration in the presence of enzymatic preparations Pectinex Yield Mash and Rapidase, dry matter content increased by 40.9 and $56.2 \%$, respectively. After 120 min, dry matter content nearly doubled.
Fig. 3 Changes in dry matter content (a), water loss (b), and solids gain (c) in highbush blueberry fruits during osmotic dehydration at $30{ }^{\circ} \mathrm{C}$ : without pretreatment (OD-30 $\left.{ }^{\circ} \mathrm{C}\right)$; preceded by pretreatment with ultrasound (US+OD-30 ${ }^{\circ} \mathrm{C}$ ); preceded by pretreatment with ultrasound and under low pressure (US+V+OD-30 ${ }^{\circ} \mathrm{C}$ ). In the tables attached, the same letter in different cells within a given column indicates a lack of statistical differences $(\alpha=0.05)$ between the results at particular processing times a

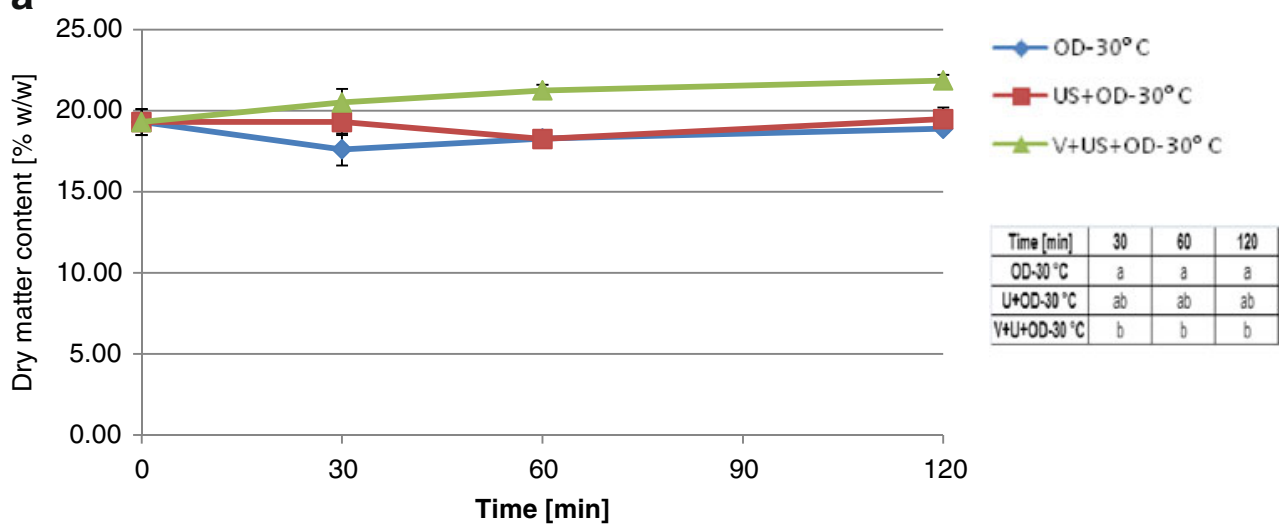

b
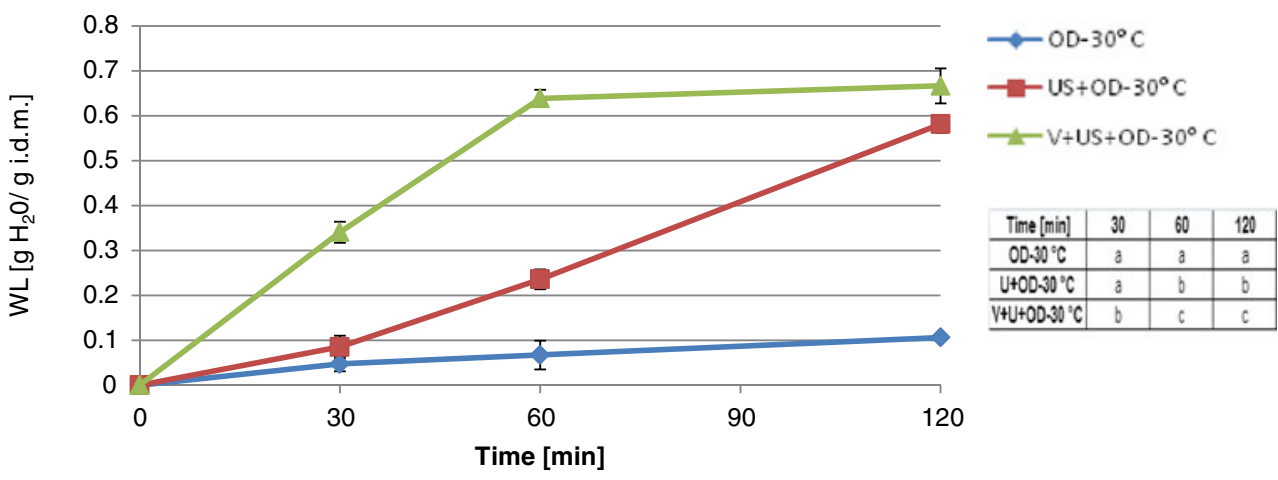

C

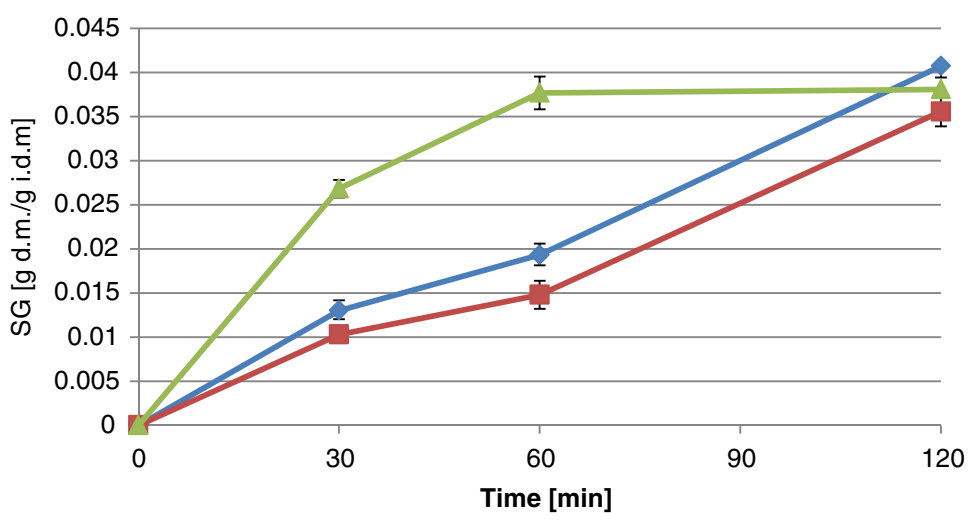


Fig. 4 Changes in dry matter content (a), water loss (b), and solids gain (c) in highbush blueberry fruits during osmotic dehydration at $30{ }^{\circ} \mathrm{C}(\mathrm{OD}$ $30{ }^{\circ} \mathrm{C}$ ); in the presence of Pectinex Yield Mash enzyme $\left(\mathrm{ODP}-30{ }^{\circ} \mathrm{C}\right)$; and in the presence of Rapidase C-80 Max enzyme (ODR- $\left.30{ }^{\circ} \mathrm{C}\right)$. In the tables attached, the same letter in different cells within a given column indicates a lack of statistical differences $(\alpha=0.05)$ between the results at particular processing times a
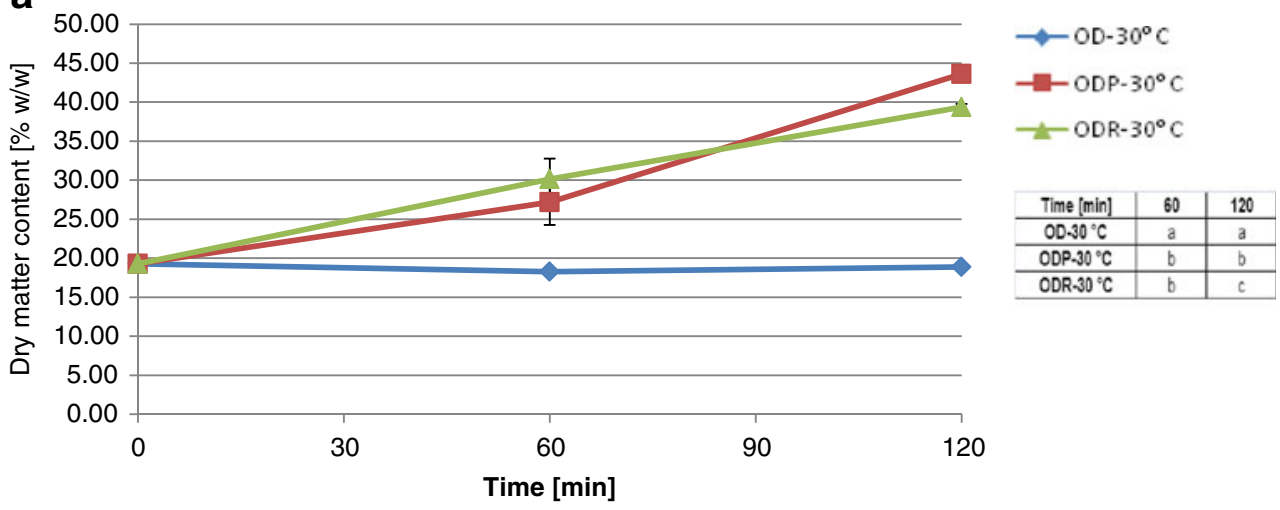

b
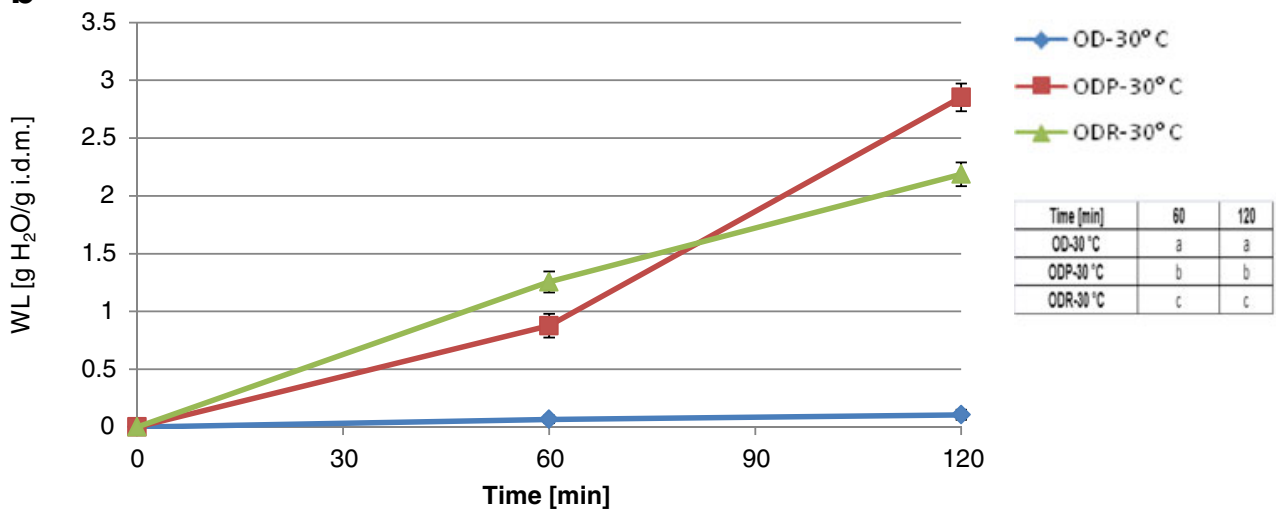

C

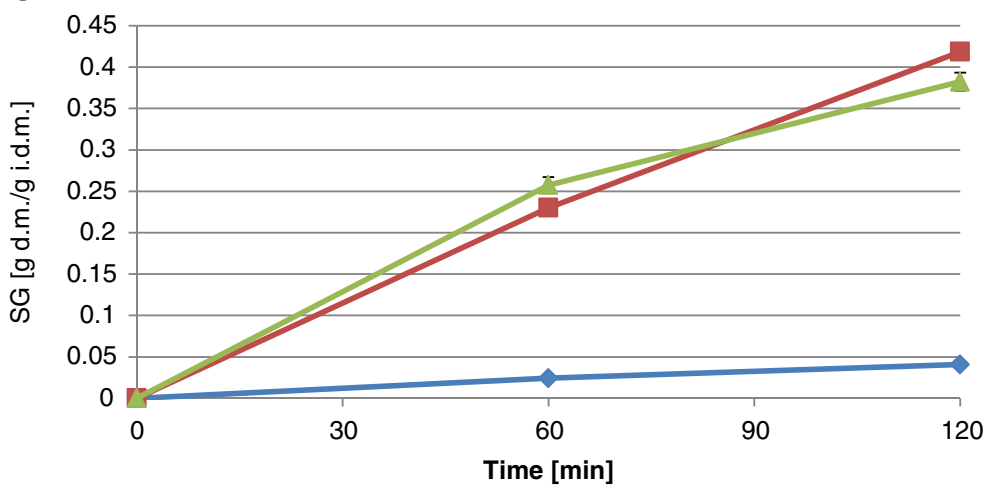

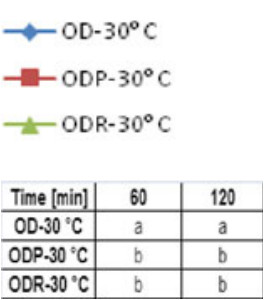

20
In both cases, considerable water loss was observed. After $2 \mathrm{~h}$ of processing, the value amounted to $2.19-2.85 \mathrm{~g} \mathrm{H}_{2} \mathrm{O} / \mathrm{g}$ i.d.m. Solids gain reached a level of $0.38-0.42 \mathrm{~g}$ d.m./g i.d.m. However, fruits dehydrated under these conditions were characterized by an unacceptable appearance and texture. The presence of enzymes led to hydrolysis of pectins in the raw material, resulting in the loss of firmness. Osmotic dehydration with solutions containing pectinolytic enzymes was also performed by Grabowski et al. (2007) on cranberries. However, in his case, the kinetics of the process was unsatisfactory, as after $10 \mathrm{~h}$ the decrease in water content was $200 \mathrm{~g} / 100 \mathrm{~g}$ of dry matter.

Figure 5a shows that the most promising pretreatment method among those tested is the application of lipolytic and pectinolytic enzymes. In this case, the increase in dry matter content after $1 \mathrm{~h}$ of dehydration was $26.1 \%$. The level of water loss (Fig. 5b) was higher than that of solids gain (Fig. 5c). At the same time, both parameters were the highest for this method of pretreatment among the tested ones. When only pectinase or lipase was used, water loss was lower by 40 and $47 \%$, respectively, and solids gain was lower by 73 and $76 \%$, respectively, after $1 \mathrm{~h}$ of dehydration. The results show that the epidermis of the fruits was disturbed, which facilitated mass transfer. The epidermis of highbush blueberries consists of waxes, cutin, and pectins. A wax layer is present on the fruit surface, visible as a white bloom (Skurtys et al. 2011). The use of lipase catalyzes the 
Fig. 5 Changes in dry matter content (a), water loss (b), and solids gain (c) in highbush blueberry fruits during osmotic dehydration at $30^{\circ} \mathrm{C}$ : without pretreatment $\left(\mathrm{OD}-30{ }^{\circ} \mathrm{C}\right)$; preceded by pretreatment by immersion in a water bath containing: pectinolytic enzyme $\left(\mathrm{P}+\mathrm{OD}-30{ }^{\circ} \mathrm{C}\right)$; lipolytic enzyme $\left(\mathrm{L}+\mathrm{OD}-30^{\circ} \mathrm{C}\right)$; pectinolytic enzyme and following a water bath containing lipolytic enzyme (P $\left.+\mathrm{L}+\mathrm{OD}-30{ }^{\circ} \mathrm{C}\right)$. In the tables attached, the same letter in different cells within a given column indicates a lack of statistical differences $(\alpha=0.05)$ between the results at particular processing times a

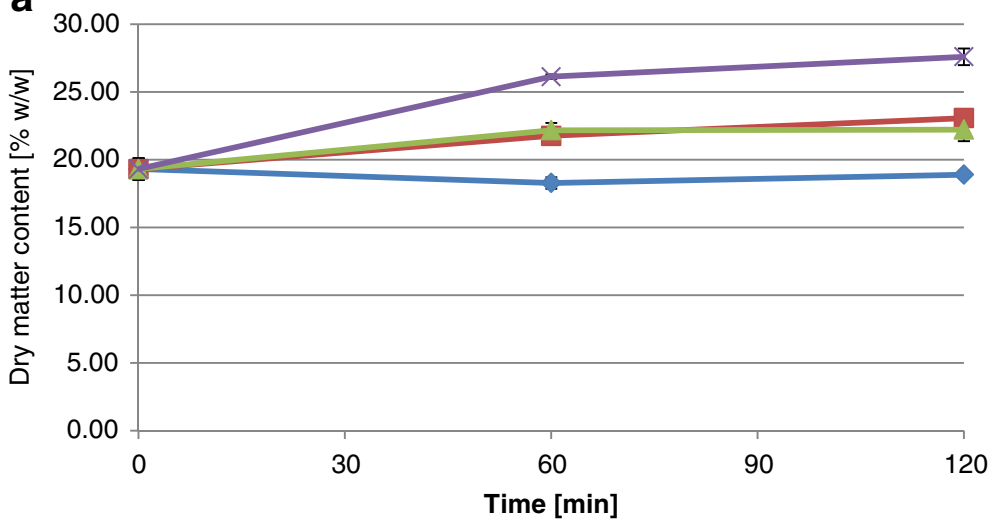

$\rightarrow O O D-30^{\circ} \mathrm{C}$

$-\mathrm{C}+\mathrm{OD}-30^{\circ} \mathrm{C}$

$\rightarrow-L+O D-30^{\circ} \mathrm{C}$

$\because \mathrm{L}+\mathrm{P}+\mathrm{OD}-30^{\circ} \mathrm{C}$

\begin{tabular}{|c|c|c|}
\hline Time $[\min ]$ & 60 & 120 \\
\hline $00 \cdot 30^{\circ} \mathrm{C}$ & $\mathrm{a}$ & $\mathrm{a}$ \\
\hline$P+00 \cdot 30^{\circ} \mathrm{C}$ & $b$ & $b$ \\
\hline$L+00 \cdot 30^{\circ} \mathrm{C}$ & $b$ & $b$ \\
\hline$L+P 0 D \cdot 30^{\circ} \mathrm{C}$ & 6 & $c$ \\
\hline
\end{tabular}

b

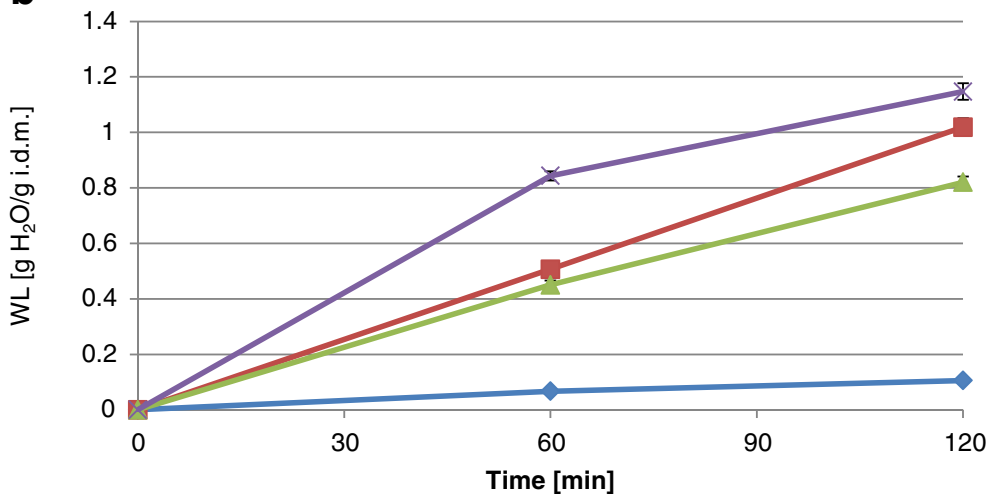

$\longrightarrow \mathrm{OD}-30^{\circ} \mathrm{C}$

$-\mathrm{C}-\mathrm{P}+\mathrm{OD}-30^{\circ} \mathrm{C}$

$\rightarrow-L+O D-30^{\circ} \mathrm{C}$

$\therefore \mathrm{L}+\mathrm{P}+\mathrm{OD}-30^{\circ} \mathrm{C}$

\begin{tabular}{c|c|c|} 
Time [min] & 60 & 120 \\
\hline$O D-30^{\circ} \mathrm{C}$ & $a$ & $a$ \\
\hline$P+O D-30^{\circ} \mathrm{C}$ & $b$ & $b$ \\
\hline$L+O D-30^{\circ} \mathrm{C}$ & $b$ & $c$ \\
\hline$L+P O D-30^{\circ} \mathrm{C}$ & $\mathrm{c}$ & $d$ \\
\hline
\end{tabular}

C
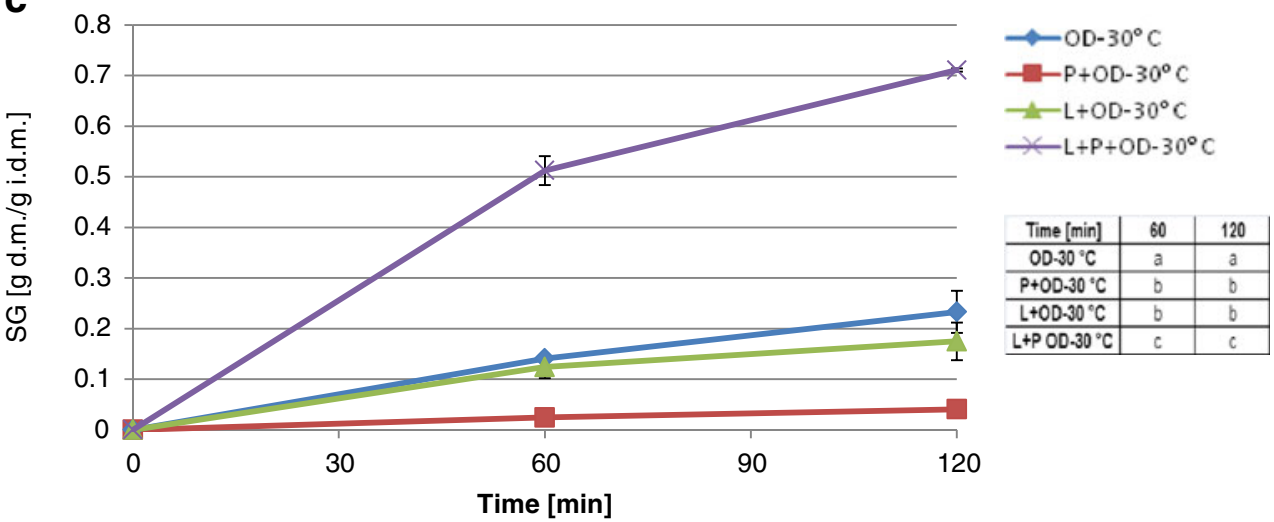

Fig. 6 Changes in total polyphenol content in highbush blueberry fruits during osmotic dehydration (OD) in $65^{\circ}$ Brix sucrose solution (without pretreatment) at different temperatures $(30,40,50,60$, and $70{ }^{\circ} \mathrm{C}$ ). In the tables attached, the same letter in different cells within a given column indicates a lack of statistical differences $(\alpha=0.05)$ between the results at particular processing times

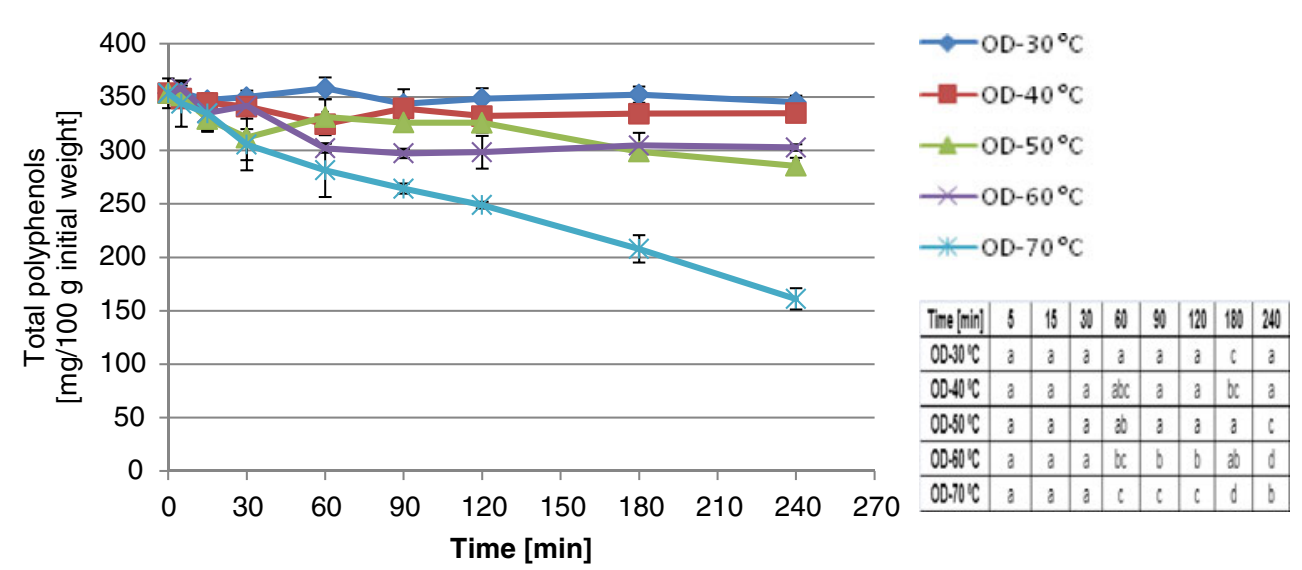


Table 1 Total polyphenols in the whole amount of fruits subjected to processing (before dehydration), in the whole amount of processed fruits (after dehydration), and in the whole amount of syrup after dehydration

\begin{tabular}{|c|c|c|c|c|c|}
\hline \multirow{5}{*}{$\begin{array}{l}\text { Table } 1 \text { Total polyphenols in } \\
\text { the whole amount of fruits sub- } \\
\text { jected to processing (before de- } \\
\text { hydration), in the whole amount } \\
\text { of processed fruits (after dehy- } \\
\text { dration), and in the whole } \\
\text { amount of syrup after } \\
\text { dehydration }\end{array}$} & \multicolumn{2}{|c|}{ Before dehydration } & \multicolumn{2}{|c|}{ After dehydration } & \multirow[t]{2}{*}{ Fruits + syrup $[\mathrm{mg}]$} \\
\hline & Time $[\mathrm{min}]$ & Fruits [mg] & Fruits [mg] & Syrup [mg] & \\
\hline & 5 & $49.53 \pm 0.38$ & $49.61 \pm 1.30$ & nd & $49.61 \pm 1.30$ \\
\hline & 15 & $49.20 \pm 0.47$ & $48.31 \pm 1.35$ & nd & $48.31 \pm 1.35$ \\
\hline & 30 & $49.88 \pm 0.35$ & $49.37 \pm 1.23$ & nd & $49.37 \pm 1.23$ \\
\hline & 60 & $48.04 \pm 0.47$ & $48.67 \pm 0.93$ & nd & $48.67 \pm 0.93$ \\
\hline & 90 & $49.13 \pm 0.85$ & $48.73 \pm 1.10$ & nd & $48.73 \pm 1.10$ \\
\hline & 120 & $49.06 \pm 0.47$ & $48.38 \pm 1.81$ & $0.11 \pm 0.02$ & $48.49 \pm 1.84$ \\
\hline & 180 & $48.60 \pm 0.05$ & $48.43 \pm 0.98$ & $0.13 \pm 0.05$ & $48.55 \pm 0.93$ \\
\hline & 240 & $49.26 \pm 0.81$ & $48.11 \pm 1.64$ & $0.27 \pm 0.01$ & $48.38 \pm 1.50$ \\
\hline & \multicolumn{5}{|l|}{ OD $-40^{\circ} \mathrm{C}$} \\
\hline & 5 & $48.01 \pm 1.08$ & $47.36 \pm 1.73$ & nd & $47.36 \pm 1.73$ \\
\hline & 15 & $47.60 \pm 1.43$ & $46.40 \pm 2.19$ & $1.54 \pm 0.10$ & $47.93 \pm 2.29$ \\
\hline & 30 & $50.43 \pm 2.92$ & $48.64 \pm 1.86$ & $1.26 \pm 0.11$ & $49.89 \pm 1.97$ \\
\hline & 60 & $51.65 \pm 0.49$ & $47.44 \pm 3.31$ & $0.92 \pm 0.10$ & $48.36 \pm 3.21$ \\
\hline & 90 & $51.56 \pm 0.51$ & $49.49 \pm 0.92$ & $1.18 \pm 0.57$ & $50.67 \pm 0.34$ \\
\hline & 120 & $50.51 \pm 2.18$ & $47.46 \pm 1.70$ & $2.07 \pm 0.29$ & $49.52 \pm 1.99$ \\
\hline & 180 & $52.00 \pm 0.61$ & $49.22 \pm 3.69$ & $1.61 \pm 0.34$ & $50.83 \pm 4.03$ \\
\hline & 240 & $49.07 \pm 3.52$ & $46.51 \pm 3.75$ & $1.76 \pm 0.01$ & $48.27 \pm 3.76$ \\
\hline & \multicolumn{5}{|l|}{$\mathrm{OD}-50^{\circ} \mathrm{C}$} \\
\hline & 5 & $49.98 \pm 0.05$ & $49.71 \pm 1.68$ & nd & $49.71 \pm 1.68$ \\
\hline & 15 & $48.63 \pm 1.05$ & $45.31 \pm 2.33$ & nd & $45.31 \pm 2.33$ \\
\hline & 30 & $48.56 \pm 0.68$ & $42.88 \pm 4.77$ & $3.30 \pm 0.84$ & $46.18 \pm 3.93$ \\
\hline & 60 & $48.26 \pm 0.37$ & $45.22 \pm 1.96$ & $2.19 \pm 0.50$ & $47.40 \pm 0.46$ \\
\hline & 90 & $47.74 \pm 1.30$ & $44.05 \pm 2.22$ & $2.86 \pm 0.70$ & $46.91 \pm 3.92$ \\
\hline & 120 & $48.11 \pm 0.50$ & $44.35 \pm 0.78$ & $2.03 \pm 0.53$ & $46.38 \pm 0.24$ \\
\hline & 180 & $48.41 \pm 1.47$ & $40.92 \pm 0.31$ & $6.57 \pm 1.42$ & $47.48 \pm 1.73$ \\
\hline & 240 & $48.79 \pm 0.28$ & $39.42 \pm 0.81$ & $6.76 \pm 1.05$ & $46.19 \pm 2.24$ \\
\hline & \multicolumn{5}{|l|}{ OD- $60^{\circ} \mathrm{C}$} \\
\hline & 5 & $47.81 \pm 0.90$ & $48.47 \pm 1.66$ & nd & $48.47 \pm 1.66$ \\
\hline & 15 & $48.62 \pm 0.47$ & $46.11 \pm 2.89$ & nd & $46.11 \pm 2.89$ \\
\hline & 30 & $49.13 \pm 0.98$ & $47.51 \pm 2.60$ & $2.57 \pm 0.37$ & $50.07 \pm 2.97$ \\
\hline & 60 & $48.32 \pm 0.29$ & $41.28 \pm 0.83$ & $2.53 \pm 1.15$ & $43.81 \pm 1.98$ \\
\hline & 90 & $48.23 \pm 0.24$ & $38.72 \pm 1.80$ & $3.97 \pm 0.44$ & $44.52 \pm 1.23$ \\
\hline & 120 & $49.62 \pm 0.79$ & $41.86 \pm 1.47$ & $5.61 \pm 0.34$ & $47.47 \pm 1.12$ \\
\hline & 180 & $48.98 \pm 0.48$ & $42.24 \pm 2.04$ & $7.72 \pm 0.02$ & $49.96 \pm 2.06$ \\
\hline & 240 & $49.28 \pm 0.40$ & $42.21 \pm 0.08$ & $8.61 \pm 0.11$ & $50.81 \pm 0.19$ \\
\hline & \multicolumn{5}{|l|}{ OD-70 ${ }^{\circ} \mathrm{C}$} \\
\hline & 5 & $48.33 \pm 0.56$ & $47.01 \pm 2.43$ & $1.29 \pm 0.42$ & $48.30 \pm 2.85$ \\
\hline & 15 & $47.76 \pm 0.52$ & $45.21 \pm 2.69$ & $2.39 \pm 0.04$ & $47.61 \pm 2.73$ \\
\hline & 30 & $46.90 \pm 0.59$ & $40.55 \pm 2.44$ & $4.90 \pm 0.33$ & $45.44 \pm 2.11$ \\
\hline & 60 & $47.68 \pm 0.48$ & $37.95 \pm 3.00$ & $8.23 \pm 0.04$ & $46.19 \pm 2.96$ \\
\hline \multirow{4}{*}{$\begin{array}{l}\text { Process conditions: } 65^{\circ} \text { Brix su- } \\
\text { crose solution at } 1: 4 \text { fruit to syr- } \\
\text { up ratio, without pretreatment, } \\
\text { temperature: } 30-70{ }^{\circ} \mathrm{C} \\
\text { nd not detected }\end{array}$} & 90 & $47.05 \pm 1.39$ & $35.17 \pm 0.42$ & $13.05 \pm 0.66$ & $48.23 \pm 0.23$ \\
\hline & 120 & $47.09 \pm 0.03$ & $33.16 \pm 0.39$ & $13.92 \pm 2.12$ & $47.08 \pm 1.73$ \\
\hline & 180 & $47.14 \pm 0.45$ & $27.73 \pm 1.96$ & $21.14 \pm 1.84$ & $48.87 \pm 0.13$ \\
\hline & 240 & $48.05 \pm 0.38$ & $21.90 \pm 1.17$ & $26.28 \pm 1.11$ & $48.19 \pm 2.28$ \\
\hline
\end{tabular}

cleavage of ester bonds in the waxes, facilitating the migration of water from the material. Given the other results presented in Fig. 5, preliminary immersion of the fruits in a bath with lipolytic enzymes alone is not so effective. 

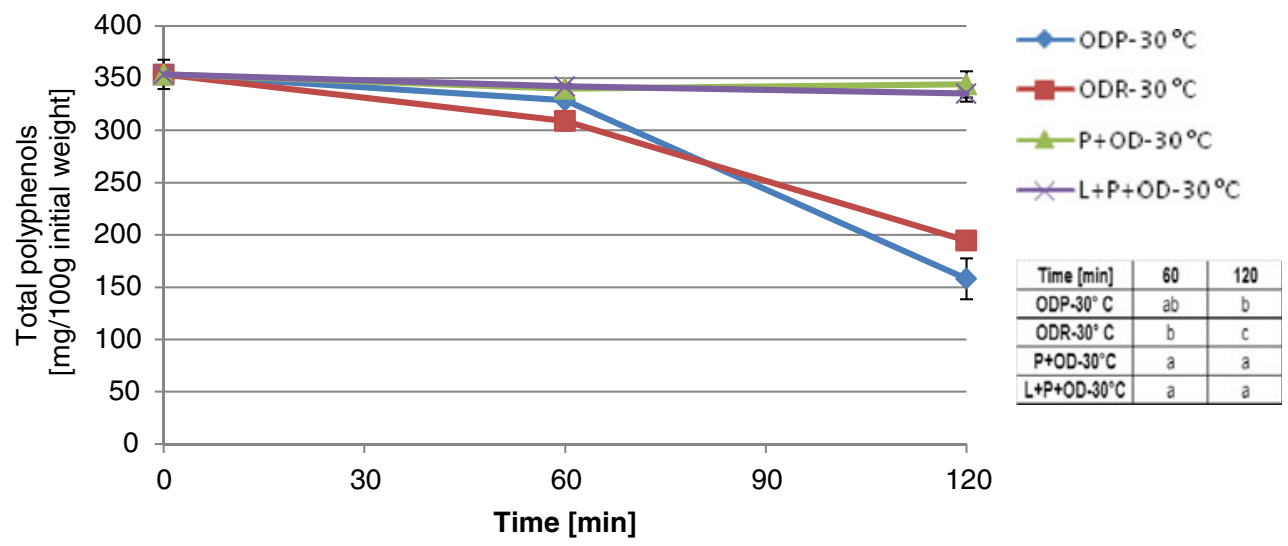

Fig. 7 Changes in total polyphenol content in osmotically dehydrated fruits: $a$ during dehydration in the presence of pectinolytic enzymes: Pectinex Yield Mash (ODP- $30{ }^{\circ} \mathrm{C}$ ), Rapidase C-80 Max (ODR-30 ${ }^{\circ} \mathrm{C}$ ), $b$ during dehydration preceded by pretreatment with pectinolytic enzyme $\left(\mathrm{P}+\mathrm{OD}-30{ }^{\circ} \mathrm{C}\right)$; c) during dehydration preceded by pretreatment with

lipolytic and pectinolytic enzymes $\left(\mathrm{P}+\mathrm{L}+\mathrm{OD}-30{ }^{\circ} \mathrm{C}\right)$. In the tables attached, the same letter in different cells within a given column indicates a lack of statistical differences $(\alpha=0.05)$ between the results at particular processing times

Additional hydrolysis of pectins improves the conditions of mass transfer, especially that it facilitates the diffusion of osmotic agent to the fruits, as can be seen from data on solids gain (Fig. 5c). It needs to be remembered that dehydration of fruits pretreated with enzymatic solutions is not accompanied by any unfavorable changes in shape or texture, which shows that apparently cell membranes are not damaged.

The Influence of Pretreatment and Osmotic Dehydration on Polyphenol Content in Blueberries

temperature. After $1 \mathrm{~h}$ of dehydration, the greatest loss in polyphenol content $(20.4 \%)$ was observed at the highest temperature $\left(70^{\circ} \mathrm{C}\right)$, while a temperature of $60^{\circ} \mathrm{C}$ led to a loss of $14.6 \%$. The smallest losses $(\downarrow 5 \%)$ were observed at $30^{\circ} \mathrm{C}$. Polyphenol content decreased also with time of dehydration. Thus, data show that the intensification of dehydration through increasing temperature will occur at the cost of polyphenol content. This can be explained by higher migration of phenolic compounds to the dehydrating solution as a result of higher temperature (an increase in temperature leads to a rise in the diffusion flow rate, and high temperature also hampers the selectivity of cell membranes; Lewicki et al. 1998). The fact that migration played a substantial role in decreasing polypheThe present experiments showed that the dehydration process affected total polyphenol content in highbush blueberry fruits (Fig. 6) and that it largely depended on the process nol content is confirmed by data presented in Table 1, which

Table 2 Total polyphenols in the whole amount of fruits subjected to processing (before dehydration), in the whole amount of processed fruits (after dehydration), and in the whole amount of syrup after dehydration

\begin{tabular}{|c|c|c|c|c|}
\hline \multicolumn{2}{|c|}{ Before dehydration } & \multicolumn{2}{|c|}{ After dehydration } & \multirow[t]{2}{*}{ Fruits+syrup [mg } \\
\hline Time $[\mathrm{min}]$ & Fruits $[\mathrm{mg}]$ & Fruits $[\mathrm{mg}]$ & Syrup [mg] & \\
\hline 60 & $54.02 \pm 0.46$ & $47.23 \pm 1.64$ & $2.71 \pm 0.25$ & $49.95 \pm 1.89$ \\
\hline 120 & $54.84 \pm 0.91$ & $30.20 \pm 0.22$ & $24.13 \pm 0.75$ & $54.33 \pm 0.96$ \\
\hline \multicolumn{5}{|l|}{ ODR-30 ${ }^{\circ} \mathrm{C}$} \\
\hline 60 & $53.36 \pm 0.34$ & $49.62 \pm 1.95$ & $3.02 \pm 0.85$ & $52.64 \pm 1.11$ \\
\hline 120 & $54.30 \pm 0.17$ & $24.26 \pm 2.60$ & $29.12 \pm 0.50$ & $53.38 \pm 3.11$ \\
\hline \multicolumn{5}{|l|}{$\mathrm{P}+\mathrm{OD}-30{ }^{\circ} \mathrm{C}$} \\
\hline 60 & $53.12 \pm 0.45$ & $51.06 \pm 0.40$ & $1.53 \pm 0.24$ & $52.59 \pm 0.16$ \\
\hline 120 & $52.03 \pm 0.38$ & $50.62 \pm 0.56$ & $2.30 \pm 0.25$ & $52.92 \pm 0.80$ \\
\hline \multicolumn{5}{|c|}{$\mathrm{L}+\mathrm{P}+\mathrm{OD}-30^{\circ} \mathrm{C}$} \\
\hline 60 & $53.18 \pm 0.38$ & $51.40 \pm 0.60$ & $1.95 \pm 0.43$ & $53.35 \pm 0.17$ \\
\hline 120 & $53.74 \pm 0.58$ & $50.62 \pm 0.51$ & $3.20 \pm 0.39$ & $53.82 \pm 0.91$ \\
\hline
\end{tabular}

Process conditions: $65^{\circ}$ Brix sucrose solution at $1: 4$ fruit to syrup ratio, at $30^{\circ} \mathrm{C}$, pretreatment with pectinolytic enzyme $\left(\mathrm{P}+\mathrm{OD}-30{ }^{\circ} \mathrm{C}\right)$ or with lipolytic and pectinolytic enzymes $\left(\mathrm{P}+\mathrm{L}+\mathrm{OD}-30{ }^{\circ} \mathrm{C}\right)$, or without pretreatment but with dehydration in the presence of pectinolytic enzymes $\left[\right.$ Pectinex Yield Mash (ODP-30 $\left.{ }^{\circ} \mathrm{C}\right)$ or Rapidase C-80 Max (ODR-30 $\left.\left.{ }^{\circ} \mathrm{C}\right)\right]$ 
Table 3 Identification of anthocyanins in blueberry fruits using mass spectroscopy

$t_{\mathrm{R}}$ retention time

\begin{tabular}{llccc}
\hline Peak & Anthocyanin & $t_{\mathrm{R}}(\mathrm{min})$ & {$[\mathrm{M}]^{+}(\mathrm{m} / \mathrm{z})$} & $\mathrm{MS} / \mathrm{MS}(\mathrm{m} / \mathrm{z})$ \\
\hline 1 & Delphinidin-3-O-galactoside & 3.7 & 465 & 303 \\
2 & Delphinidin-3-O-glucoside & 4.1 & 465 & 303 \\
3 & Cyanidin-3-O-galactoside, & 4.8 & 449 & 287 \\
4 & Cyanidin-3-O-glucoside & 5.3 & 449 & 287 \\
5 & Petunidin-3-O-galactoside, & 5.8 & 479 & 287 \\
6 & Petunidin-3-O-glucoside & 6.5 & 479 & 317 \\
7 & Petunidin-3-O-arabinoside & 7.5 & 449 & 317 \\
& Peonidin-3-O-galactoside & & 463 & 301 \\
8 & Peonidin-3-O-glucoside, & 8.2 & 463 & 301 \\
9 & Malvidin-3-O-galactoside & 8,6 & 493 & 331 \\
10 & Malvidin-3-O-glucoside & 9.5 & 493 & 331 \\
11 & Malvidin-3-O-arabinoside & 10.6 & 463 & 331 \\
12 & Malvidin+pentose & 14.1 & 463 & 331 \\
13 & Malvidin+acetoyl+hexose (I) & 14.8 & 535 & 331 \\
14 & Malvidin+acetoyl+hexose (II) & 15.5 & 535 & 331 \\
15 & Malvidin+acetoyl+hexose (III) & 18.5 & 535 & 331 \\
\hline
\end{tabular}

shows the balance of total polyphenols in fruits and syrups before and after dehydration. As can be seen, after dehydration syrups contained some amounts of polyphenolic substances, especially at higher temperatures; $13.8,17.5$, and $54.7 \%$ of total polyphenols present in blueberries before dehydration migrated to syrups after $4 \mathrm{~h}$ of processing at 50,60, and $70{ }^{\circ} \mathrm{C}$, respectively. Results obtained by Devic et al. (2010), who osmotically dehydrated apple cubes, also confirm that the retention of phenolic compounds drops with increasing temperature. Polyphenols may also migrate (under special circumstances) into the fruits. The use of grape seed extract as an osmotic solution in the process of dehydrating apples and bananas led to the infusion of phenolic compounds into the dehydrated material (Różek et al. 2010).
What is interesting is that a comparison of total polyphenols in the whole system (fruits + syrup) before and after dehydration indicates that, even at higher temperatures, blueberry polyphenols were characterized by a relatively high stability (Table 1). After $4 \mathrm{~h}$ of dehydration at 30 $70{ }^{\circ} \mathrm{C}$, the loss of polyphenols caused by degradation was $5.3 \%$ at the most.

The most substantial drop in total polyphenol content was observed during osmotic dehydration with pectinolytic enzymes (Fig. 7). After $120 \mathrm{~min}$, the content of phenolic compounds nearly halved. This can be explained by the enzymatic degradation of pectin in cell walls, which led to increased transfer of vacuolar sap to the osmotic solution, also causing substantial polyphenol migration.

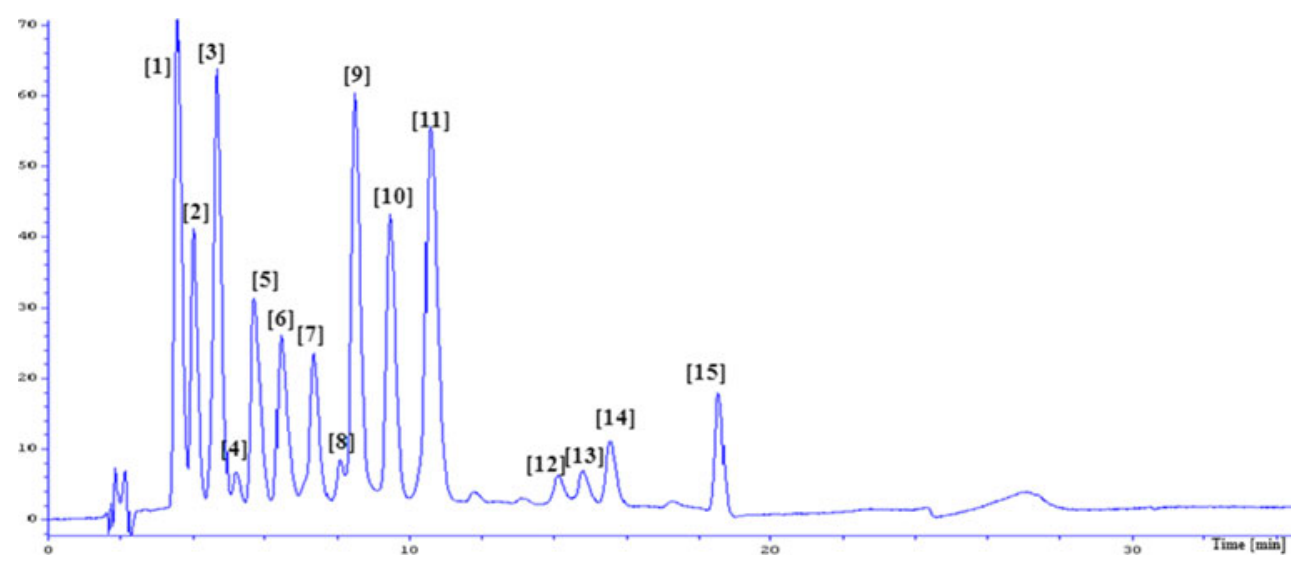

Fig. 8 HPLC chromatogram of blueberry fruits with detection at $520 \mathrm{~nm}$. Compounds: [1] delphinidin-3-galactoside, [2] delphinidin3-glucoside, [3] cyanidin-3-galactoside, delphinidin-3-arabinoside, [4] cyanidin-3-glucoside, [5] petunidin-3-galactoside, cyanidin-3arabinoside, [6] petunidin-3-glucoside, [7] peonidin-3-galactoside and petunidin-3-arabinoside, [8] peonidin-3-glucoside, malvidin-3galactoside, [9] malvidin-3-galactoside, [10] malvidin-3-glucoside, [11] malvidin-3-arabinoside, [12] malvidin-3-O-pentoside, [13] malvidin+acetoyl+hexose (I), [14] malvidin+acetoyl+hexose (II), [15] malvidin+acetoyl+hexose (III) 


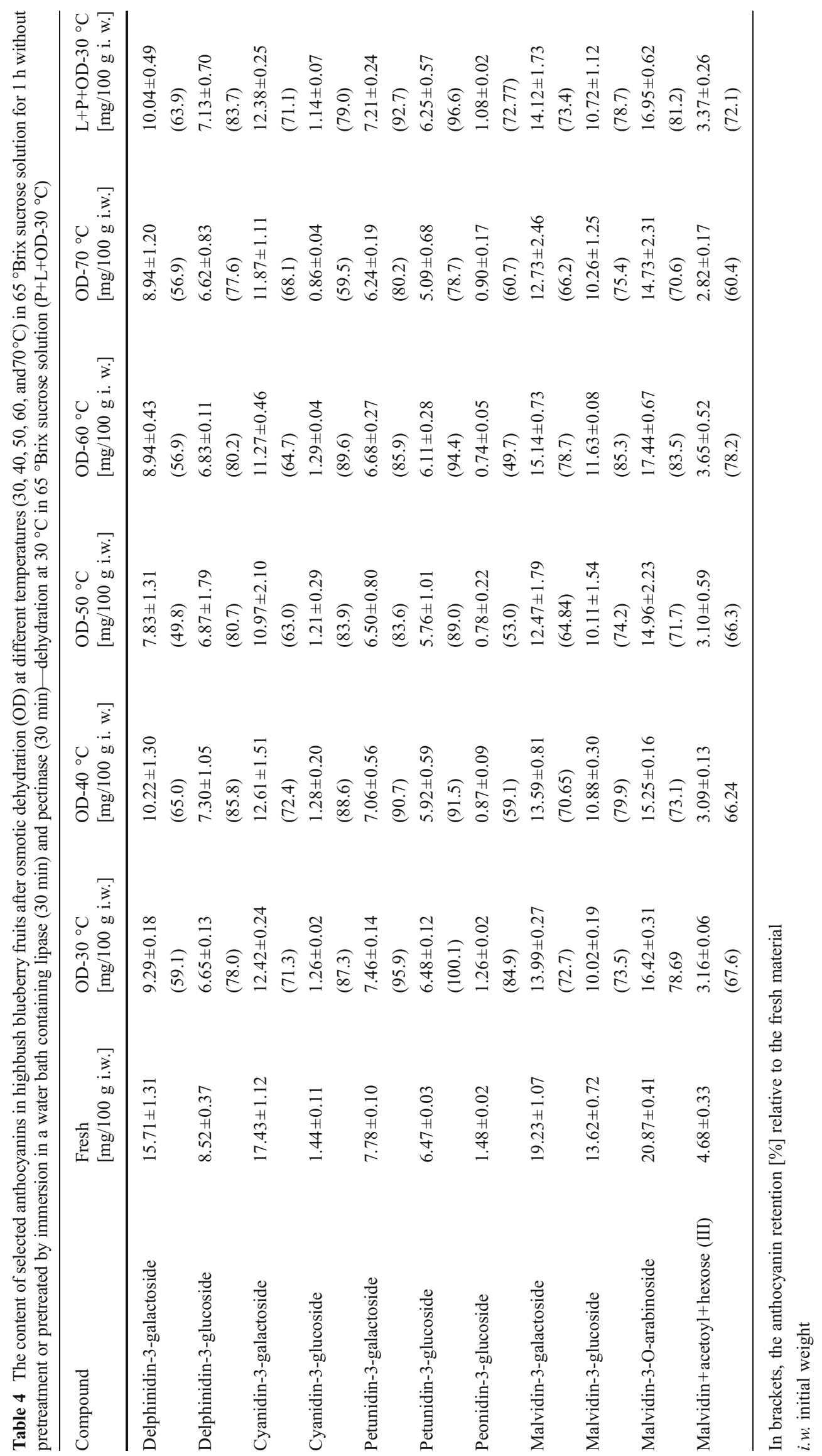


Table 5 Amounts of selected polyphenols: in the whole amount of fruits subjected to processing (before dehydration), in the whole amount of processed fruits (after dehydration), and in the whole amount of syrup after dehydration
Process conditions: $65^{\circ}$ Brix sucrose solution at 1:4 fruit to syrup ratio, without pretreatment, $1 \mathrm{~h}$ of dehydration at $30-70{ }^{\circ} \mathrm{C}$ or pretreatment with lipolytic and pectinolytic enzymes $(\mathrm{P}+\mathrm{L}$ $\left.+\mathrm{OD}-30{ }^{\circ} \mathrm{C}\right), 1 \mathrm{~h}$ of dehydration at $30{ }^{\circ} \mathrm{C}$

nd not detected

\begin{tabular}{|c|c|c|c|c|}
\hline \multicolumn{2}{|c|}{ Before dehydration } & \multicolumn{2}{|c|}{ After dehydration } & \multirow[t]{2}{*}{ Fruits + syrup $[\mathrm{mg}]$} \\
\hline Time $[\mathrm{min}]$ & Fruits $[\mathrm{mg}]$ & Fruits $[\mathrm{mg}]$ & Syrup [mg] & \\
\hline \multicolumn{5}{|c|}{ Delphinidin-3-O-galactoside } \\
\hline $\mathrm{OD}-30{ }^{\circ} \mathrm{C}$ & $1.72 \pm 0.01$ & $1.64 \pm 0.08$ & nd & $1.71 \pm 0.12$ \\
\hline $\mathrm{OD}-40{ }^{\circ} \mathrm{C}$ & $1.79 \pm 0.02$ & $1.67 \pm 0.17$ & nd & $1.67 \pm 0.17$ \\
\hline $\mathrm{OD}-50{ }^{\circ} \mathrm{C}$ & $1.67 \pm 0.01$ & $1.43 \pm 0.02$ & $0.20 \pm 0.00$ & $1.64 \pm 0.02$ \\
\hline $\mathrm{OD}-60{ }^{\circ} \mathrm{C}$ & $1.68 \pm 0.01$ & $1.40 \pm 0.20$ & $0.20 \pm 0.00$ & $1.61 \pm 0.20$ \\
\hline $\mathrm{OD}-70{ }^{\circ} \mathrm{C}$ & $1.65 \pm 0.02$ & $1.21 \pm 0.17$ & $0.35 \pm 0.00$ & $1.56 \pm 0.22$ \\
\hline $\mathrm{L}+\mathrm{P}-\mathrm{OD}-30{ }^{\circ} \mathrm{C}$ & $1.84 \pm 0.01$ & $1.51 \pm 0.06$ & $0.22 \pm 0.00$ & $1.73 \pm 0.07$ \\
\hline \multicolumn{5}{|c|}{ Cyanidin-3-O-galactoside } \\
\hline OD-30 ${ }^{\circ} \mathrm{C}$ & $2.06 \pm 0.02$ & $1.77 \pm 0.03$ & $0.17 \pm 0.01$ & $1.94 \pm 0.04$ \\
\hline $\mathrm{OD}-40{ }^{\circ} \mathrm{C}$ & $2.14 \pm 0.02$ & $1.81 \pm 0.05$ & $0.15 \pm 0.00$ & $1.96 \pm 0.04$ \\
\hline $\mathrm{OD}-50{ }^{\circ} \mathrm{C}$ & $1.80 \pm 0.02$ & $1.50 \pm 0.00$ & $0.25 \pm 0.00$ & $1.74 \pm 0.00$ \\
\hline $\mathrm{OD}-60{ }^{\circ} \mathrm{C}$ & $2.01 \pm 0.01$ & $1.54 \pm 0.00$ & $0.31 \pm 0.00$ & $1.85 \pm 0.01$ \\
\hline $\mathrm{OD}-70{ }^{\circ} \mathrm{C}$ & $1.98 \pm 0.02$ & $1.61 \pm 0.05$ & $0.79 \pm 0.00$ & $2.00 \pm 0.51$ \\
\hline $\mathrm{L}+\mathrm{P}-\mathrm{OD}-30{ }^{\circ} \mathrm{C}$ & $2.21 \pm 0.02$ & $1.91 \pm 0.05$ & $0.31 \pm 0.00$ & $2.07 \pm 0.17$ \\
\hline \multicolumn{5}{|c|}{ Petunidin-3-O-galactoside } \\
\hline $\mathrm{OD}-30{ }^{\circ} \mathrm{C}$ & $1.09 \pm 0.01$ & $0.99 \pm 0.02$ & $0.03 \pm 0.00$ & $1.02 \pm 0.02$ \\
\hline $\mathrm{OD}-40{ }^{\circ} \mathrm{C}$ & $1.14 \pm 0.01$ & $1.09 \pm 0.03$ & $0.03 \pm 0.00$ & $1.12 \pm 0.03$ \\
\hline $\mathrm{OD}-50{ }^{\circ} \mathrm{C}$ & $1.06 \pm 0.01$ & $0.78 \pm 0.00$ & $0.06 \pm 0.00$ & $0.84 \pm 0.00$ \\
\hline OD- $60{ }^{\circ} \mathrm{C}$ & $1.06 \pm 0.01$ & $0.92 \pm 0.00$ & $0.07 \pm 0.00$ & $0.99 \pm 0.00$ \\
\hline $\mathrm{OD}-70{ }^{\circ} \mathrm{C}$ & $1.05 \pm 0.01$ & $0.84 \pm 0.03$ & $0.34 \pm 0.01$ & $1.01 \pm 0.21$ \\
\hline $\mathrm{L}+\mathrm{P}-\mathrm{OD}-30^{\circ} \mathrm{C}$ & $1.17 \pm 0.01$ & $1.05 \pm 0.03$ & $0.09 \pm 0.00$ & $1.09 \pm 0.04$ \\
\hline \multicolumn{5}{|c|}{ Malvidin-3- $O$-arabinoside } \\
\hline $\mathrm{OD}-30{ }^{\circ} \mathrm{C}$ & $2.25 \pm 0.02$ & $2.15 \pm 0.03$ & nd & $2.15 \pm 0.03$ \\
\hline OD- $40{ }^{\circ} \mathrm{C}$ & $2.35 \pm 0.02$ & $2.39 \pm 0.07$ & nd & $2.39 \pm 0.07$ \\
\hline OD- $50{ }^{\circ} \mathrm{C}$ & $2.20 \pm 0.02$ & $2.03 \pm 0.02$ & $0.22 \pm 0.01$ & $2.25 \pm 0.03$ \\
\hline $\mathrm{OD}-60{ }^{\circ} \mathrm{C}$ & $2.20 \pm 0.01$ & $1.97 \pm 0.03$ & $0.25 \pm 0.01$ & $2.22 \pm 0.02$ \\
\hline $\mathrm{OD}-70{ }^{\circ} \mathrm{C}$ & $2.17 \pm 0.02$ & $1.77 \pm 0.03$ & $0.39 \pm 0.03$ & $2.16 \pm 0.06$ \\
\hline $\mathrm{L}+\mathrm{P}-\mathrm{OD}-30^{\circ} \mathrm{C}$ & $2.42 \pm 0.02$ & $2.12 \pm 0.05$ & $0.21 \pm 0.03$ & $2.33 \pm 0.03$ \\
\hline
\end{tabular}

The best method of blueberry pretreatment prior to dehydration seems to be the use of pectinolytic and lipolytic preparations. This method is characterized both by low losses of polyphenolic compounds (resulting mainly from migration which follows from the balance of polyphenols presented in Table 2) as compared to fresh material (5.1\% after $1 \mathrm{~h}$ of dehydration; Fig. 7) and by a substantial increase in dry matter content after dehydration $(26.1 \%$ after $1 \mathrm{~h}$ of dehydration, Fig. 5a).

Considering the above results, pretreatment with pectinolytic and lipolytic enzymes may have practical implications, as it enables the intensification of the dehydration-impregnation process without inducing substantial losses in phenolic compounds while preserving the acceptable shape of the fruits (no softening of the fruits was observed). The considerable increase in solids gain after using both enzymes increases possibilities for the fortification of osmo-dried products with desirable substances (for example oligosaccharides; Matusek et al. 2008) from a hypertonic solution.
An important class of polyphenolic compounds in highbush blueberry fruits are anthocyanins ( $\mathrm{Gu}$ et al. 2003, 2004; Wu and Prior 2005). According to literature data, in highbush blueberry fruits, anthocyanins are found mostly in the skin, while the pulp contains only small or trace amounts of these compounds (Riihinen et al. 2008). Furthermore, the content of particular anthocyanins in highbush blueberry fruits varies substantially, depending on the cultivar and place of cultivation (Connor et al. 2002; Lata et al. 2005; Lohachoompol et al. 2008). Due to the large range of monoglycosides and the fact that they may undergo acylation, 14 different forms of anthocyanins have been identified in highbush blueberry fruits (Lohachoompol et al. 2008). Cho et al. (2004) reported the following distribution of particular monomers: delphinidin (27-40\%), malvidin (22-33\%), petunidin (19-26\%), cyanidin (6-14\%), peonidin (1-5\%), and acylated forms $(9 \%)$. The MS experiments conducted in this study (Table 3 ) indicated the presence of 16 anthocyanins (the HPLC profile shown in 
Fig. 8 presents 15 peaks of anthocyanins; one of them corresponds to two compounds). The most abundant ones included monoglycosides of malvidin $(58.4 \mathrm{mg} / 100 \mathrm{~g})$, delphinidin $(24.2 \mathrm{mg} / 100 \mathrm{~g})$, and cyanidin $(18.8 \mathrm{mg} / 100 \mathrm{~g})$ (Table 4). The retention of particular anthocyanins depended on osmotic dehydration conditions. The average levels of particular anthocyanins in the dehydrated material (after $1 \mathrm{~h}$ ) amounted to at least $50 \%$ as compared to fresh material. The lowest levels of anthocyanin compounds were observed in fruits dehydrated at $70{ }^{\circ} \mathrm{C}$, with the retention ranging from 57 to $80 \%$. Irrespective of the applied osmotic dehydration temperature, the retention of the following compounds was the highest: petunidin-3-galactoside (minimum $80 \%$ retention at $1 \mathrm{~h}$ ) and petunidin-3-glucoside (minimum $78 \%$ ). The study also examined changes in particular polyphenols during osmotic dehydration following fruit pretreatment with lipolytic and pectinolytic enzymes. The experiments showed that anthocyanin retention was at least $64 \%$ (after $1 \mathrm{~h}$ of dehydration). The highest anthocyanin retention was found for petunidin-3-glucoside (95.4\%) and petunidin-3-galactoside $(92.3 \%)$. The balance of some selected anthocyanins (occurring in considerable amounts in blueberries) shown in Table 5 indicates that migration to a hypertonic solution rather than degradation is the major cause of decreasing the anthocyanin levels in the fruits processed under the tested conditions.

\section{Conclusions}

The factors influencing osmotic dehydration of highbush blueberry fruits include time and temperature, as well as the fruit pretreatment method. At $30-50{ }^{\circ} \mathrm{C}$, dehydration is not very effective, while the application of higher temperatures leads to substantial losses of phenolic compounds in the dehydrated material $(30 \%$ after $2 \mathrm{~h}$ of dehydration at $70{ }^{\circ} \mathrm{C}$ ). Initial immersion of fruits in pectinolytic and lipolytic enzymes leads to a greater increase of dry matter content $(26.1 \%)$ with a phenolic retention of $96 \%$ and with the retention of individual anthocyanins amounting to at least $64 \%$ after $1 \mathrm{~h}$ of dehydration at $30^{\circ} \mathrm{C}$.

Open Access This article is distributed under the terms of the Creative Commons Attribution License which permits any use, distribution, and reproduction in any medium, provided the original author(s) and the source are credited.

\section{References}

Barnes, J. S., Nguyen, H. P., Shen, S., \& Schug, K. A. (2009). General method for extraction of blueberry anthocyanins and identification using high performance liquid chromatography-electrospray ionization-ion trap-time of flight-mass spectrometry. Journal of Chromatography, 1216, 4728-4735.
Behsnilian, D., \& Spiess, W. E. L. (2006). Osmotic dehydration of fruits and vegetable. IUFoST, 1857-1869.

Bórquez, R. M., Canales, E. R., \& Redon, J. P. (2010). Osmotic dehydration of raspberries with vacuum pretreatment followed by microwave-vacuum drying. Journal of Food Engineering, 99, 121-127.

Castrejón, A. D. R., Eichholz, I., Rohn, S., Kroh, L. W., \& HuyskensKeil, S. (2008). Phenolic profile and antioxidant activity of highbush blueberry (Vacciniumcorymbosum L.) during fruit maturation and ripening. Food Chemistry, 109, 564-572.

Chiralt, A., \& Talens, P. (2005). Physical and chemical changes induced by osmotic dehydrationin plant tissues. Journal of Food Engineering, 67, 167-177.

Cho, M. J., Howard, L., Prior, R. L., \& Clark, J. (2004). Flavonoid glycosides and antioxidant capacity of various blackberry, blueberry and red grape genotypes determined by high-performance liquid chromatography/mass spectrometry. Journal of the Science of Food and Agriculture, 84, 1771-1782.

Cho, M. J., Howard, L., Prior, R. L., \& Clark, J. (2005). Flavonol glycosides and antioxidant capacity of various blackberry and blueberry genotypes determined by high-performance liquid chromatography/mass spectrometry. Journal of the Science of Food and Agriculture, 85, 2149-2158.

Connor, A. M., Luby, J. J., \& Tong, C. B. S. (2002). Genotypic and environmental variation in antioxidant activity, total phenolic content and anthocyanin content among blueberry cultivars. American Society for Horticultural Science, 127(1), 89-97.

Deng, Y., \& Zhao, Y. (2008). Effects of pulsed-vacuum and ultrasound on the osmodehydration kinetics and microstructure of apples (Fuji). Journal of Food Engineering, 85(1), 84-93.

Devic, E., Guyot, S., Daudin, J. D., \& Bonazzi, C. (2010). Effect of temperature and cultivar on polyphenol retention and mass transfer during osmotic dehydration of apples. Journal of Agricultural and Food Chemistry, 58(1), 606-614.

Falade, K. O., \& Igbeka, J. I. (2007). Osmotic dehydration of tropical fruitsand vegetables. Food Reviews International, 23, 373-405.

Fernandes, F. A. N., \& Rodrigues, S. (2008). Application of ultrasound and ultrasound-assisted osmotic dehydration in drying of fruits. Drying Technology, 26, 1509-1516.

Fernandes, F. A. N., \& Rodrigues S. (2011). Ultrasound application as pre-treatment for drying of fruits. In P. S. Taoukis, et al. (Eds), Proceedings of the International Congress on Engineering and Food, vol III (pp. 1987-1989). Athens, Greece: Cosmosware.

Fernandes, F. A. N., Gallăo, M. I., \& Rodrigues, S. (2009). Effect of osmosis and ultrasound on pineapple cell tissue structure during dehydration. Journal of Food Engineering, 90, 186-190.

Gao, L., \& Mazza, G. (1994). Quantitation and distribution of simple and acylatedanthocyanins and other phenolics in blueberries. Journal of Food Science, 59, 1057-1059.

Grabowski, S., Marcotte, M., Quan, D., Taherian, A. R., Zareifard, M. R., Poirier, M., et al. (2007). Kinetics and quality aspects of Canadian blueberries and cranberries dried by osmo-convective method. Drying Technology, 25, 367-374.

Gu, L., Kelm, M. A., Hammerstone, J. F., Beecher, G., Holden, J., Haytowitz, D., et al. (2003). Screening of foods containing proanthocyanidins and their structural characterization using LC-MS/ MS and thiolytic degradation. Journal of Agricultural and Food Chemistry, 51, 7513-7521.

Gu, L., Kelm, M. A., Hammerstone, J. F., Beecher, G., Holden, J., Haytowitz, D., et al. (2004). Concentrations of proanthocyanidins in common foods and estimations of normal consumption. The Journal of Nutrition, 134, 613-617.

Häkkinen, S. H., \& Törrönen, A. R. (2000). Content of favonols and selected phenolic acids in strawberries and Vaccinium species: influence of cultivar, cultivation site and technique. Food Research International, 33, 517-524. 
Heim, K. E., Tagliaferro, A. R., \& Bobilya, D. J. (2002). Flavonoid antioxidants: chemistry, metabolism and structure-activity relationships. The Journal of Nutritional Biochemistry, 13 (10), 572-584.

Janowicz, M., Domian, E., Lenart, A., \& Wójcik, M. (2008). Effect of pressure during osmotic dehydration on the course of convective drying of apple tissue. Acta Agrophysica, 12 (3), 675-688.

Joseph, J. A., Shukitt-Hale, B., \& Casadesus, G. (2005). Reversing the deleterious effects of aging on neuronal communication and behavior: beneficial properties of fruit polyphenolic compounds. American Society for Clinical Nutrition, 81, 313-316.

Kalt, W., McDonald, J. E., Ricker, R. D., \& Lu, X. (1999). Anthocyanin content and profile within and among blueberry species. Canadian Journal of Plant Science, 79, 617-623.

Krikorian, R., Shidler, M. D., Nash, T. A., Kalt, W., VinqvistTymchuck, M. R., Shukitt-Hale, B., et al. (2010). Blueberry supplementation improves memory in older adults. Journal of Agricultural and Food Chemistry, 58, 3996-4000.

Krupa, T., \& Tomala, K. (2007). Antioxidant capacity, anthocyanin content profile in "Bluecrop" blueberry fruit. Vegetable Crops Research Bulletin, 66, 129-141.

Łata, B., Trapczyńska, A., \& Mike, A. (2005). Effect of cultivar and harvest date on thiols, ascorbate and phenolic compounds content in blueberries. Acta Scientiarum Polonorum, Hortorum Cultus, 4 (1), 163-171.

Lewicki, P. P., Kowalska, H., \& Lenart, A. (1998). Effect of temperature on mass transfer during osmotic dehydration of plant tissue. Proc. of Industrial Seminar, Industrial Aapplication of Osmotic Dehydration Treatments of Food, Bertinoro, 44-50.

Lohachoompol, V., Mulholland, M., Srzednicki, G., \& Craske, J. (2008). Determination of anthocyanins in various cultivars of highbush and rabbiteye blueberries. Food Chemistry, 111, 249254.

Manach, C., Scalbert, A., Morand, C., Rémésy, C., \& Jiménez, L. (2004). Polyphenols: food sources and bioavailability. American Society for Clinical Nutrition, 79, 727-747.

Matusek, A., Czukor, B., \& Merész, P. (2008). Comparison of sucrose and fructo-oligosaccharides as osmotic agents in apple. Innovative Food Science and Emerging Technologies, 9, 365-373.

Matuska, M., Lenart, A., \& Lazarides, N. (2006). On the use of edible coatings to monitor osmotic dehydration kinetics for minimal solids uptake. Journal of Food Engineering, 72, 85-91.

Mazza, G. (2005). Compositional and functional properties of saskatoon berry and blueberry. International Journal of Fruit Science, 5(3), 101-119.

Mújica-Paz, H., Valdez-Fragoso, A., López-Malo, A., Palou, E., \& Welti-Chanes, J. (2003). Impregnation and osmotic dehydration of some fruits: effect of the vacuum pressure and syrup concentration. Journal of Food Engineering, 57, 305-314.

Nsonzi, F., \& Ramaswamy, H. S. (1998). Osmotic dehydration kinetic of blueberries. Drying Technology, 16(3-5), 725-741.

Ochmian, I., Grajkowski, J., Mikiciuk, G., Ostrowska, K., \& Chełpiński, P. (2009). Mineral composition of highbush blueberry leaves and fruits depending on substrate type used for cultivation. Jouranal of Elementology, 14(2), 509-516.

Ohnihisi, S., Fujii, T., \& Miyawaki, O. (2003). Freezing injury and rheological properties of agricultural products. Food Science and Technology Research, 9, 367-371.

Perron, N. R., \& Brumaghim, J. L. (2009). A review of the antioxidant mechanisms of polyphenol compounds related to iron binding. Cell Biochemistry and Biophysics, 53, 75-100.

Petti, S., \& Scully, C. (2009). Polyphenols, oral health and disease: a review. Journal of Dentistry, 37, 413-423.

Pietta, P. G. (2000). Flavonoids as antioxidants. Journal of Natural Products, 63, 1035-1042.
Pokorný, J. (2007). Are natural antioxidants better-and safer-than synthetic antioxidants? European Journal of Lipid Science and Technology, 109, 629-642.

Rastogi, N. K., Eshtiaghi, M. N., \& Knorr, D. (1999). Accelerated mass transfer during osmotic dehydration of high intensity electrical field pulse pretreated carrots. Journal of Food Science, 64 (6), 1020-1023.

Rastogi, N. K., Raghavarao, K. S. M. S., Niranjan, K., \& Knorr, D. (2002). Recent developments in osmotic dehydration: methods to enhance mass transfer. Trends in Food Science and Technology, $13,48-59$

Riihinen, K., Jaakola, L., Kärenlampi, S., \& Hohtola, A. (2008). Organ-specific distribution of phenolic compounds in bilberry (Vacciniummyrtillus) and 'northblue' blueberry (Vaccinium corymbosum $x$ V. Angustifolium). Food Chemistry, 110(1), 156-160.

Rodrigues, S., Gomes, M. C. F., Gallão, M. I., \& Fernandes, F. A. N. (2009). Effect of ultrasound-assisted osmotic dehydration on cell structure of sapotas. Journal of the Science of Food and Agriculture, 89, 665-670.

Różek, A., Garcia-Pérez, J. V., López, F., Güell, C., \& Ferrando, M. (2010). Infusion of grape phenolics into fruits and vegetables by osmotic treatment: phenolic stability during air drying. Journal of Food Engineering, 99, 142-150.

Saurel, R., Raoult-Wack, A.-L., Rios, G., \& Guilbert, S. (1994a). Mass transfer phenomena during osmotic dehydration of apple I. Fresh plant tissue. International Journal of Food Science and Technology, 29, 531-542.

Saurel, R., Raoult-Wack, A.-L., Rios, G., \& Guilbert, S. (1994b). Mass transfer phenomena during osmotic dehydration of apple II. Frozen plant tissue. International Journal of Food Science and Technology, $29,543-550$

Singleton, V. L., \& Rossi, J. A. (1965). Colorimetry of total phenolics with phosphomolybolic-phosphotungstic acid reagents. American Journal of Enology and Viticulture, 16, 144-158.

Skupień, K. (2006). Chemical composition of selected cultivars of highbush blueberry fruit (Vacciniumcorymbosum L.). Folia Horticulturae, 18(2), 47-56.

Skurtys, O., Velásquez, P., Henriquez, O., Matiacevich, S., Enrione, J., \& Osorio, F. (2011). Wetting behavior of chitosan solutions on blueberry epicarp with or without epicuticular waxes. Food Science and Technology, 44(6), 1449-1457.

Taruscio, T. G., Barney, D. L., \& Exon, J. (2004). Content and profile of flavanoid and phenolic acid compounds in conjunction with the antioxidant capacity for a variety of northwest Vacciniumberries. Journal of Agricultural and Food Chemistry, 52, 3169-3176.

Torreggiani, D., \& Bertolo, G. (2001). Osmotic pre-treatments in fruit processing: chemical, physical, and structural effects. Journal of Food Engineering, 49, 247-253.

Wang, H., Cao, G., \& Prior, R. L. (1996). Total antioxidant capacity of fruits. Journal of Agricultural and Food Chemistry, 44, 701-705.

Wang, S. Y., Chen, C. T., Sciarappa, W., Wang, C. Y., \& Camp, M. J. (2008). Fruit quality, antioxidant capacity, and flavonoid content of organically and conventionally grownblueberries. Journal of Agricultural and Food Chemistry, 56, 57885794.

Wu, X., \& Prior, R. L. (2005). Systematic identification and characterization of anthocyanins by HPLC-ESI-MS/MS in common foods in the United States: fruits and berries. Journal of Agricultural and Food Chemistry, 53, 2589-2599.

Yi, W., Akoh, C. C., Fischer, J., \& Krewer, G. (2006). Effects of phenolic compounds in blueberries and muscadine grapes on HepG2 cell viability and apoptosis. Food Research International, $39,628-638$. 
You, Q., Wang, B., Chen, F., Huang, Z., Wang, X., \& Luo, P. G. (2011). Comparison of anthocyanins and phenolics in organically and conventionally grown blueberries in selected cultivars. Food Chemistry, 125, 201-208.

Zadernowski, R., Naczk, M., \& Nesterowicz, J. (2005). Phenolic acid profiles in some small berries. Journal of Agricultural and Food Chemistry, 53, 2118-2124.
Zafra-Stone, S., Yasmin, T., Bagchi, M., Chatterjee, A., Vinson, J. A., \& Debasis, B. (2007). Berry anthocyanins as novel antioxidants in human health and disease prevention. Molecular Nutrition \& Food Research, 51, 675-683.

Zheng, W., \& Wang, S. Y. (2003). Oxygen radical absorbing capacity of phenolics in blueberries, cranberries, chokeberries, and lingonberries. Journal of Agricultural and Food Chemistry, 51, 502-509. 